\title{
Role of Vitamin K in Intestinal Health
}

\author{
Yujiao Lai ${ }^{1}$, Hori Masatoshi ${ }^{2}$, Yanbo Ma $^{3}$, Yuming Guo ${ }^{1}$ and Bingkun Zhang ${ }^{1 *}$ \\ 1 State Key Laboratory of Animal Nutrition, College of Animal Science and Technology, China Agricultural University, \\ Beijing, China, ${ }^{2}$ Department of Veterinary Pharmacology, Graduate School of Agricultural and Life Sciences, The University \\ of Tokyo, Tokyo, Japan, ${ }^{3}$ Department of Animal Physiology, College of Animal Science and Technology, Henan University of \\ Science and Technology, Luoyang, China
}

\section{OPEN ACCESS}

Edited by:

Xia Xiong,

Chinese Academy of Sciences, China

Reviewed by:

Dan Wan,

Chinese Academy of Sciences, China

Huansheng Yang,

Hunan Normal University, China

*Correspondence:

Bingkun Zhang

bingkunzhang@126.com

Specialty section:

This article was submitted to

Nutritional Immunology,

a section of the journal

Frontiers in Immunology

Received: 08 October 2021

Accepted: 02 December 2021

Published: 05 January 2022

Citation:

Lai Y, Masatoshi H, Ma Y, Guo Y and Zhang $B$ (2022) Role of Vitamin K in Intestinal Health.

Front. Immunol. 12:791565. doi: 10.3389/fimmu.2021.791565
Intestinal diseases, such as inflammatory bowel diseases (IBDs) and colorectal cancer (CRC) generally characterized by clinical symptoms, including malabsorption, intestinal dysfunction, injury, and microbiome imbalance, as well as certain secondary intestinal disease complications, continue to be serious public health problems worldwide. The role of vitamin $\mathrm{K}(\mathrm{VK})$ on intestinal health has drawn growing interest in recent years. In addition to its role in blood coagulation and bone health, several investigations continue to explore the role of VK as an emerging novel biological compound with the potential function of improving intestinal health. This study aims to present a thorough review on the bacterial sources, intestinal absorption, uptake of VK, and VK deficiency in patients with intestinal diseases, with emphasis on the effect of VK supplementation on immunity, antiinflammation, intestinal microbes and its metabolites, antioxidation, and coagulation, and promoting epithelial development. Besides, VK-dependent proteins (VKDPs) are another crucial mechanism for VK to exert a gastroprotection role for their functions of anti-inflammation, immunomodulation, and anti-tumorigenesis. In summary, published studies preliminarily show that VK presents a beneficial effect on intestinal health and may be used as a therapeutic drug to prevent/treat intestinal diseases, but the specific mechanism of VK in intestinal health has yet to be elucidated.

Keywords: VK, intestinal health, VKDPs, IBDs, intestinal disease

\section{INTRODUCTION}

Vitamin $\mathrm{K}(\mathrm{VK})$, a fat-soluble factor, is a generic term for a series of structurally related compounds (1), which shares a common ring structure of 2-methyl-1,4-naphthoquinone. However, forms of VK differ in the degree of saturation and the varying lengths of the aliphatic side chain attached to the 3position (Figure 1). VK is an essential lipid-soluble vitamin that functions as a cofactor for $\gamma$ glutamyl carboxylase (GGCX) which is an integral membrane protein and catalyzes the conversion of glutamate (Glu) residues into $\gamma$-carboxyglutamate (Gla) essentially and enables VKDPs to perform their biological functions (2). This biological process is inhibited by warfarin (Figure 2). In addition to the well-known biological function of blood coagulation and bone metabolism, emerging studies support VK involved in multiple cellular and physiological processes such as oxidative stress $(3,4)$, immune response and anti-inflammation $(5,6)$, and cancer progression $(7,8)$ 
A<smiles>CC1=CC(=O)c2ccccc2C1=O</smiles>

\section{Menadione}

(Vitamin $\mathrm{K}_{3}$ )

B

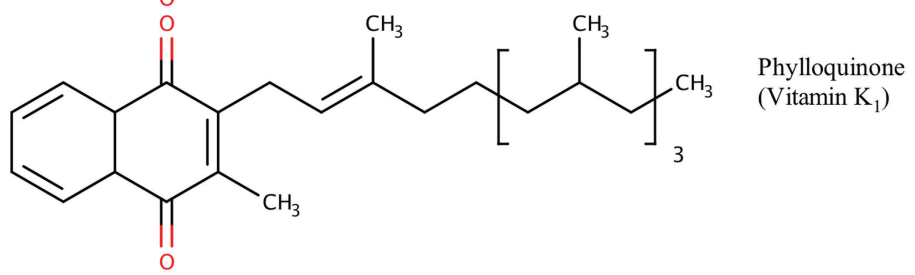

C
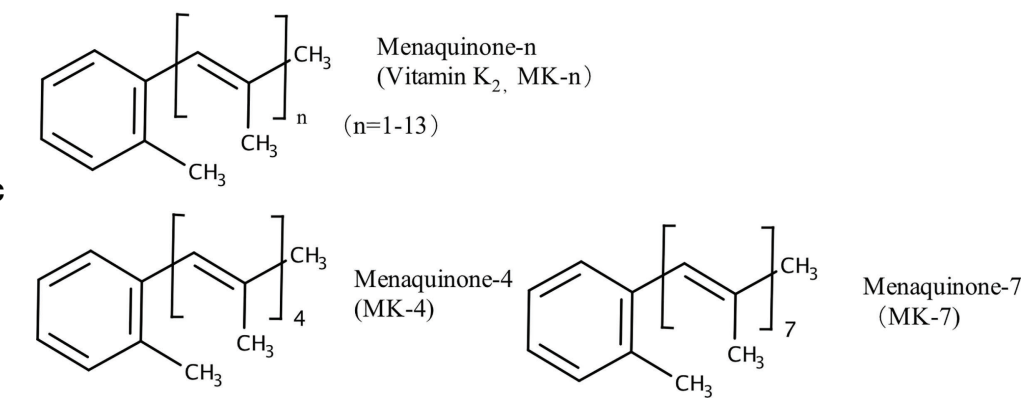

FIGURE 1 | Chemical structures of VK compounds: (A) 2-methyl-1,4-naphthoquinone (menadione, $\mathrm{K}_{3}$ ), (B) 2-methyl-3-phytyl-1,4-naphthoquinone (phylloquinone, $\mathrm{K}_{1}$ ), and (C) when $n=4$ and 7, 2-methyl-3-geranyl-geranyl-1,4-naphthoquinone (menaquinone-4, MK-4) and 2-methyl-3-all-trans-farnesyldigeranyl-1,4naphthoquinone (menaquinone-7, MK-7) are the two common forms of menaquinones $\left(\mathrm{VK}_{2}\right)$. The figure is in non-editable format.

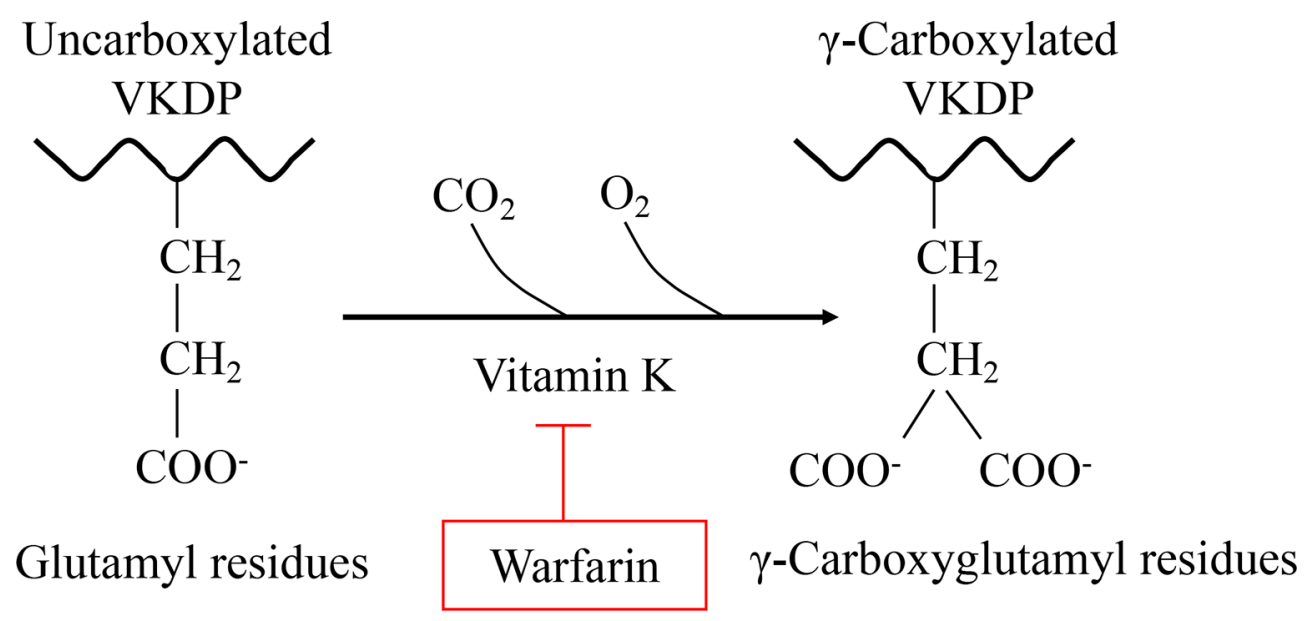

FIGURE 2 | VK is essential for the formation of Gla. Gla, a unique amino acid, is produced by a VK-dependent posttranslational modification of Glu in all Glacontaining proteins. This carboxylation process can be inhibited by warfarin.

and associated with protective and promoting roles in diverse organs or tissues, such as testis (9), brain (10-14), intestine (15$17)$, muscle $(18,19)$, bone $(20-22)$, liver $(7,23)$, kidney $(24,25)$, pancreas $(26,27)$, fat tissues (28-30), and cardiovascular system (31-34) (Figure 3).
The intestinal tract is the primary organ responsible for the digestion and absorption of nutrients. Also, the intestinal system combats invasive compounds with the help of defense mechanisms such as detoxification activities and the immune system. Factors, such as nutrition, gut environment, physiological 


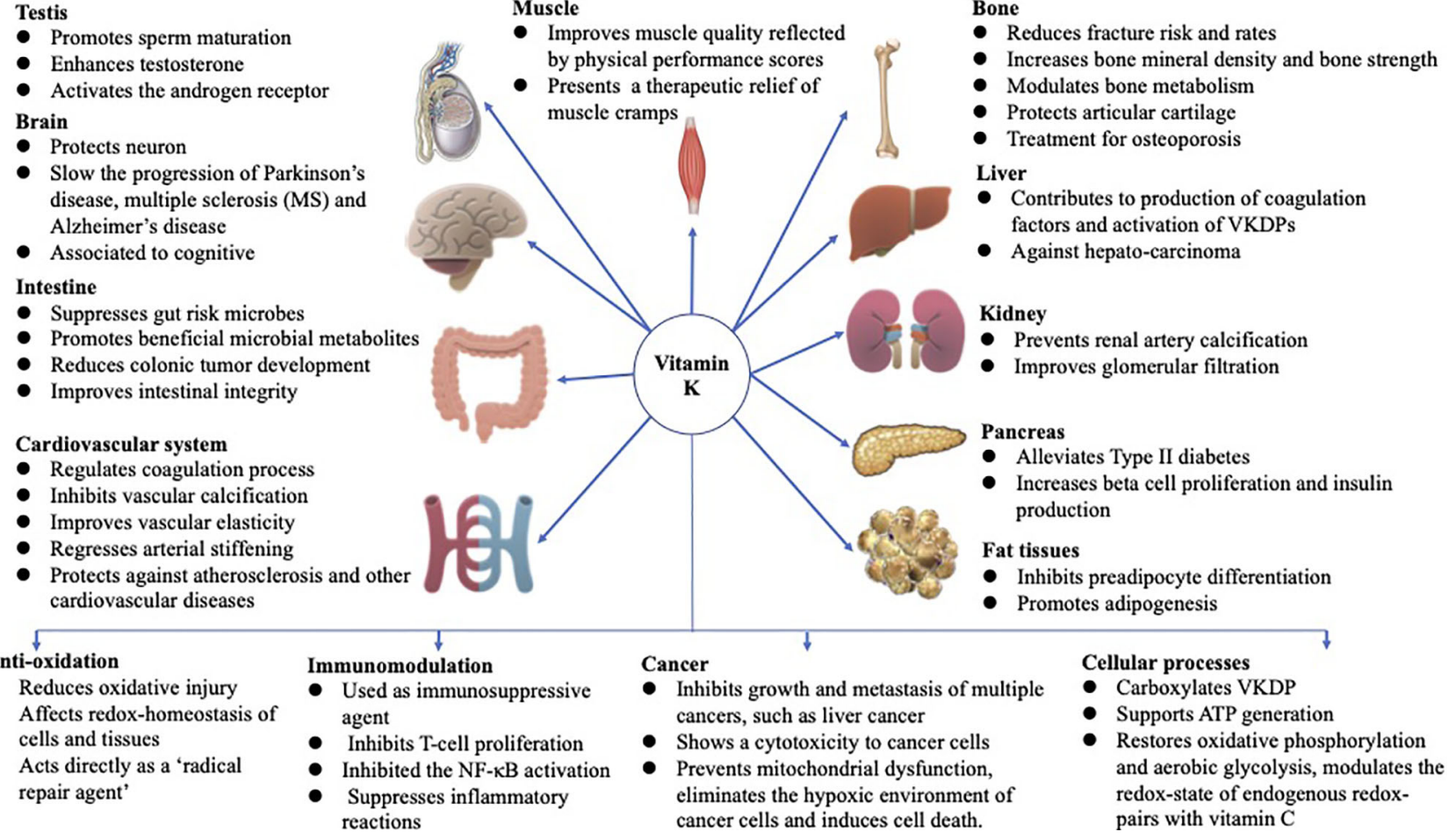

FIGURE 3 | Functions of VK in multiple-organ systems, such as testis (9), brain (10-14), intestine (15-17), muscle (18, 19), bone (20-22), liver (7, 23), kidney (24, 25), pancreas $(26,27)$, fat tissues (28-30), and cardiovascular system (31-34), and biological processes involved in anti-oxidation (3, 4), immune response and antiinflammation $(5,6)$, and cancer progression $(7,8)$, and associated with protective and promoting roles in diverse organs or tissues throughout the human body are summarized above. The figure is in a non-editable format.

status, and the microbial compositions, are likely to modulate the functionalities of the intestine. Therefore, any impairment in gut integrity may lead to enteritis, for example, inflammatory bowel diseases (IBDs). IBDs, comprising both ulcerative colitis (UC) and Crohn's disease (CD), are lifelong, chronic, immunologically inflammatory disorders of the gastrointestinal tract. It occurs as a result of altered interactions between the mucosal immune system and gut bacteria (35). The incidence of IBDs is about 1-3 in 1,000 individuals (36). Typical symptoms of IBDs include diarrhea, abdominal pain, and rectal bleeding (37), which are common worldwide, especially in western countries (38). Besides, IBDs can increase the risk of colorectal cancer (CRC), which is the third leading cause of malignant tumors (39). The aberrant immune response to gut microbes is thought to result in IBDs in genetically susceptible individuals. The host is susceptible to colonization by pathobionts resulting from functional and compositional dysbiosis of the gut microbiome. In addition, oxidative stress exerts a critical effect on the initiation and occurrence of relapses in UC (40). Therapeutic approaches, such as the regulation of interactions between the gut bacteria and the immune system, are used to restore intestinal homeostasis or reduce inflammation. In addition, when UC is in the active stage and on remission of the disease, malnutrition accounts for about $85 \%$ of patients with IBD (41). Micronutrient deficiencies, such as deficiency in VK, vitamin D, iron, selenium, zinc, folic acid, and vitamin $\mathrm{B}_{1}, \mathrm{~B}_{6}$, or $\mathrm{B}_{12}$, have also been recorded in more than half of patients with IBD (41). Administration of micronutrients therefore seems to be a novel therapeutic approach to alleviate intestinal diseases, particularly those that can relieve inflammation, reduce oxidation, and inhibit invasion of pathogenic bacteria. As a micronutrient, emerging evidence on the immunoregulatory effect of VK in intestinal health suggests novel roles for VK in gut disease health and beyond the VK typical function in hemostasis $(13,32,42,43)$.

Previous studies demonstrated that VK reduced interleukin (IL)-6 in a murine model of colitis (44); improved the antioxidant capabilities (45); improved intestinal bacteria flora (15); improved intestinal alkaline phosphatase (IAP) (46), and adiponectin (ADPN), the nuclear receptor vitamin $\mathrm{D}$ receptor (VDR), and the adenosine 5'-monophosphate (AMP)-activated protein kinase (AMPK) activity (15); contributed to blood coagulation in gastrointestinal bleeding (GIB) (47); and alleviated $\operatorname{IBD}(16,44)$ and CRC (15). Thus, gathering and summarizing the latest findings on $\mathrm{VK}$ actions in the intestine other than coagulation is important and should be summarized and elucidated by studies from laboratories. The present study focuses on the relationship between VK, intestinal health, and the mechanisms through which VK modulates intestinal microbes, exerts anti-inflammatory and antioxidant effects, and improves intestinal function. 


\section{VARIOUS SOURCES OF VK}

VK comes from natural sources and chemical synthesis (menadione, also known as $\mathrm{VK}_{3}$ ). Natural VK exists mainly in two biologically active forms: vitamin $\mathrm{K}_{1}$ (phylloquinone, also called $\mathrm{K}_{1}$ ) is present in plant margarine and vegetables (48) which is the major dietary source of VK in the US diet (49). Vitamin $\mathrm{K}_{2}\left(\mathrm{~K}_{2}\right)$ consists of a group of menaquinones (MK-n, varies from MK-4 to MK-13) is present in natto, egg yolk, meat, liver, cheese, curd cheese, and butter (48) and biosynthesized by gut bacteria (50). Among all menaquinones, MK-4 and MK-7 are the most well-studied. Information on a detailed content and adequate intake of VK in natural sources was provided in a recent review $(51,52)$. The total VK dietary intake comprises $K_{1}$, MK-4, and MK-7 (more than 60\%, 24\%, and 7\%, respectively) (53). In animals and human beings, MK-4 is catabolized from $\mathrm{K}_{1}$ with $\mathrm{K}_{3}$ as an intermediate with UbiA prenyltransferase domaincontaining 1 (UBIAD1) (54), and partially from long-chain MKs in extrahepatic tissues, for example, salivary gland, brain, pancreas, reproductive organs, kidney, and fat (1). However, when $\mathrm{K}_{1}$ isoprenoids are derived from mevalonate, merely $5 \%-$ $25 \%$ of $\mathrm{K}_{1}$ intake is converted into MK-4, followed by the synthesis of other MKs in some but not all tissues via prenylation (55). The prenylation process seems to happen independently from intestinal bacteria $(56,57)$.

Apart from the dietary intake sources, MKs are mainly synthesized by gut microbiota, predominantly in the ileum (58). MKs are abundant in the human gut, and the concentrations of different MK forms within the intestine show considerable intraindividual and interindividual variations related to heterogeneity in the intestinal microbiome composition (59). Bacteria can release MKs in lipid-soluble (60) or other forms of complexes, such as short-chain quinones (61). The major forms of MK-6 are synthesized by Eubacterium lentum, MK-7 by Veillonella, MK-8 by Escherichia coli, and MK-10 and MK-11 by Bacteroides species (50,62). However, the disparity in fecal VK content is not owing to differences in the principal dietary VK forms (i.e., $\mathrm{K}_{1}$ and MK-4), but it is based on discrepancies in the fecal content of some bacterially derived MKs (63). The intestinal bacteria are capable of producing MKs, yet information on the bioavailability of this intestinal MK supply is limited. Majority of these MKs are bound to bacterial membranes present in the gut (1). Previous studies showed that bioactivity and bioavailability differed across vitamers (64-66), with evidence approving superior bioavailability, higher bioactivity, and probably unique functions of some bacterially synthesized MK forms rather than $K_{1}(67-69)$. Even though gut bacteria synthesize a great deal of MKs, the bioavailability of bacterial menaquinone is bad in general, and diet is the principal source of functionally available $K_{2}(55,70)$. There are studies showing that a shortterm decrease in dietary VK intake is not compensated by gut bacteria synthesized MKs $(71,72)$. Actually, inadequate dietary intake (73), restorative proctocolectomy (74), IBD (75), liver dysfunction (76). chronic kidney disease (CKD) $(77,78)$, and antibiotic administration (79) could cause a VK-deficient state.

\section{INTESTINAL ABSORPTION AND METABOLISM OF VK}

Intestinal absorption of VK involves bile salt- and pancreaticdependent solubilization. Once the dietary VK reaches the intestinal lumen, it is absorbed into a mixture of bile salts, pancreatic lipolysis products, and other dietary lipids (80). Mixed micelles are absorbed by small-intestinal enterocytes and incorporated into nascent chylomicron (CM). At the same time, they are secreted from gut villi by exocytosis into the lymphatic capillaries (lacteals) through the proximal intestine (81) and then join the larger lymphatic vessels where they are released through the thoracic duct into the bloodstream (80). $\mathrm{CM}$ enters the capillary layer of peripheral tissues in the bloodstream, where it loses much of its triglyceride (TG)producing chylomicron remnant $(\mathrm{CR})$ through the action of lipoprotein lipase. The formed CR has a centralized lipid core, and only a small quantity eventually reenters the circulatory system (80) (Figure 4).

The Niemann-Pick C1-like 1 (NPCIL1) protein, the scavenger receptor class B-type I (SR-BI), and the cluster-determinant 36 (CD 36) are thought important for intestinal VK absorption (82). NPCIL1 is a primary importer for $\mathrm{K}_{1}$ in the gut, while the physiological role and significance of SR-BI and CD 36 as importers for $K_{1}$ in the small bowel need further studies (82). The absorption of dietary VK is slower than that of pure $\mathrm{K}_{1}$ due to different matrices (serum peak values at 6 vs. $4 \mathrm{~h}$ after ingestion) (83). Different forms of VK are transported by different carriers. TG-rich lipoproteins transport $\mathrm{K}_{1}$ predominantly, while lowdensity lipoproteins transport long-chain MKs primarily in the postprandial state (55). In terms of $\mathrm{K}_{2}, \mathrm{MK}-4, \mathrm{MK}-5$, and MK-6 may be most effective in nature (65). MK-7 to MK-13, which are synthesized by gut bacteria, are not efficiently absorbed with relatively increasing longer isoprene units (65).

The distribution of VK in the body organ tissue is inconsistent; $K_{1}$ was found mainly distributed in the liver, while $K_{2}$ was present in the extrahepatic tissues at higher levels (84). Besides, the concentrations of $\mathrm{K}_{1}, \mathrm{MK}-4$, and some longchain MKs presented sex-specific differences in rat tissues (liver, kidney, brain, mesenteric adipose tissue, and pancreas) in response to the dietary $\mathrm{K}_{1}$ levels (85).

The dietary $K_{1}$ was converted into $K_{3}$ in the gut, delivered to tissues, and subsequently converted into MK-4 with UBIAD1 (54, 86). In vitro, both $\mathrm{K}_{1}$ and $\mathrm{K}_{2}$ were rapidly metabolized into a mixture of quinone, hydroquinone, and epoxide (87). In humans, $\mathrm{K}_{1}$ and MKs are catabolized in the liver and excreted sharing a common degradative pathway. Initially, the polyisoprenoid side chain of VK is catabolized into two major carboxylic acid metabolites of 7-carbon [2-methyl-3-(5-carboxy-3'-methyl-2'pentenyl)-1,4-naphthoquinone] and 5-carbon side chains [2methyl-3-(3'-3'-carboxymethylpropyl)-1,4-naphthoquinone]. Then, after glucuronic acid conjugation, it is finally excreted as glucuronides in the bile and urine primarily $(55,88,89)$.

The metabolism of VK, also known as the VK epoxide cycle, occurs in a cellular pathway, involving GGCX and VK epoxide reductase (VKOR) $(55,90)$. In addition, the metabolism time of 


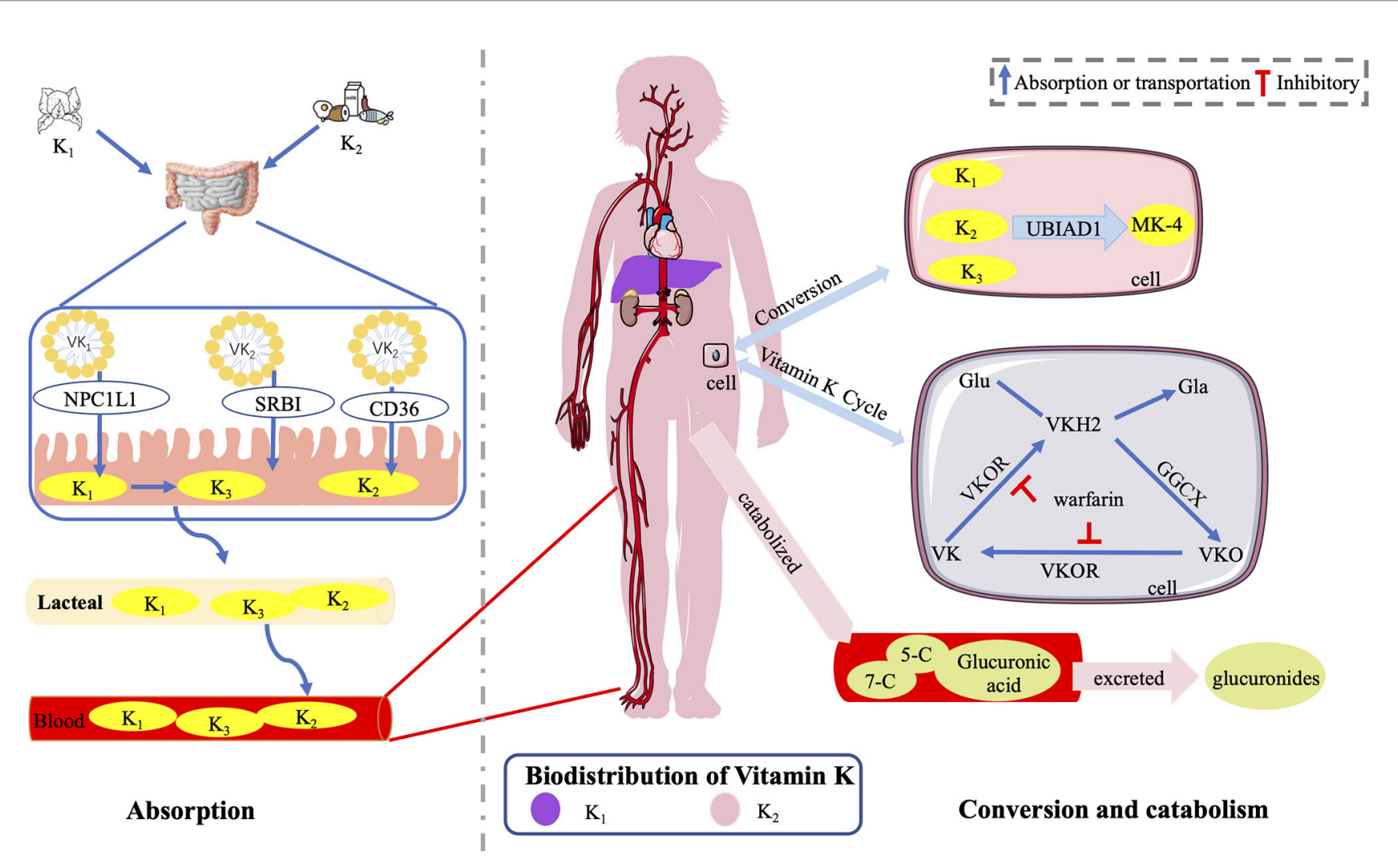

FIGURE 4 | Absorption, distribution, and catabolism of VK. Once the dietary VK reaches the intestinal lumen, it is absorbed into mixed micelles through the NPCIL1 protein, SR-BI, and CD 36. Mixed micelles are absorbed by small-intestinal enterocytes, incorporated into CM, and secreted from gut villi into lacteals. Then, they join the larger lymphatic vessels where they are released through the thoracic duct into the bloodstream. $\mathrm{K}_{1}$ is converted into $\mathrm{K}_{3}$ in the gut, delivered to tissues, and subsequently converted into MK-4 with UBIAD1. $\mathrm{K}_{1}$ is retained in the liver, while $\mathrm{K}_{2}$ is redistributed to the circulation and (extra-)hepatic tissues (51). VK epoxide cycle involving GGCX and VKOR, which is responsible for VK regeneration by converting into VK, VKH $\mathrm{H}_{2}$, and VKO. In humans, the polyisoprenoid side chain of VK is catabolized into two major carboxylic acid metabolites of 7 - and 5-carbon side chains. Then, after glucuronic acid conjugation, it is finally excreted as glucuronides in the bile and urine primarily. The figure is in a non-editable format.

different forms of VK is different. Schurgers et al. (64) found that the half-life of MK-7 was $68 \mathrm{~h}$ longer than $1-2 \mathrm{~h}$ of $\mathrm{K}_{1}$, leading to a higher steady serum concentration and storage of MK-7 (sevenfold to eightfold) during long-term intake. The change in the carboxylated osteocalcin/undercarboxylated osteocalcin ratio (cOC/ucOC) for $\mathrm{MK}-7$ was three times greater than that for $\mathrm{K}_{1}$, suggesting that the higher serum concentrations of MK-7 indicated higher tissue concentrations and better utilization of MK-7 (64). As a potent antidote of oral anticoagulation, MK-7 is three to four times more effective than $K_{1}(64)$.

\section{VK IN INTESTINAL HEALTH AND DISEASE}

\section{Gastrointestinal Disease Results in VK Deficiency and Will Be Further Exacerbated by VK Deficiency}

VK deficiency happens in patients with fat malabsorption of any cause, attributable to intestinal injury (75), cholestatic liver disease (91), or genetic disorders (92), and the use of antibiotics (79) and anticoagulants (93). VK deficiency in the appearance of abnormal prothrombin, deficient in gammacarboxyglutamic acid (94), may lead to serious bleeding and death (95-97). In IBD patients, VK deficiency occurs for the malabsorption resulting from intestinal damage (98). VK deficiency has also been reported in chronic gastrointestinal disorders (94), including IBDs (98-100) and short bowel syndrome (101). Actually, the levels of fat-soluble vitamins including $\mathrm{A}, \mathrm{D}, \mathrm{E}$, and $\mathrm{K}$ are generally lower in patients with IBD (102). The prevalence of VK deficiency was $43.7 \%$ in UC and $54.0 \%$ in $\mathrm{CD}$ (75). UC and CD, as the major forms of idiopathic IBDs, are chronic inflammatory disorders of the gastrointestinal tract (103) caused by altered interactions between gut microbiome and the mucosal immune system (35). Compared with normal controls, serum VK levels of CD patients were significantly decreased (104). VK deficiency was more common in patients with higher CD activity, in CD patients with higher mass Z-scores, and less common among children with CD treated with infliximab (75). In murine models of colitis, mice fed a K-deficient diet showed more severe body weight loss, shorter colon length, and higher histological scores than those patients with IBDs fed a K-supplemented diet often 
exhibit VK deficiency (16). In another rat model, VK deficiency also resulted in exacerbation of murine dextran sulfate sodium (DSS)-induced colitis by IL-6 production from B cells (44). There is adequate evidence to support that VK may play a key role in the progression of CD (14), and lack of VK will exacerbate inflammatory disease.

Osteoporosis is one complication resulting from the chronic character of IBD, manifested by low bone mineral density, which leads to an increased risk of fractures (105). Malabsorption of VK is one possible factor that contributes to decreased bone mineral density (BMD), a frequent complication in gastrointestinal disease $(106,107)$. There is an association between VK deficiency with bone metabolism and clinical disease activity in IBD, showing that VK status and bone mineral density (BMD) are low in CD and UC patients (104). VK deficiency and decreased BMD are highly prevalent in IBD-induced osteoporosis patients, especially CD (98). VK status in patients with $\mathrm{CD}$ was lower than that of healthy controls, which might be an etiological factor for CD-related osteopenia (13). Lower plasma VK $\left(\mathrm{K}_{1}\right.$ or $\left.\mathrm{MK}-7\right)$ levels correlate with lower BMD in patients with CD and those with UC (98). Modulating the VK status may have implications for the prevention and treatment of osteoporosis in IBD (104).

\section{VK Has Anti-Inflammation and Immunosuppressive Function in the Intestine}

The observation that high VK status was associated with lower concentrations of inflammatory markers suggests that a possible protective role by $\mathrm{VK}$ in inflammation merits further investigation (108). VK deficiency is seen in gut diseases, and VK-deficient conditions exacerbate gastrointestinal diseases (16, 44). Supplementation of VK showed different efficacy levels of immunosuppressive and anti-inflammation effects in in vitro and in vivo experiments of different patients and animals. On top of that, according to several safety assessments of $K_{2}$ and $K_{1}$ on animals and clinical and non-clinical studies together with the results of investigations conducted by reputable bodies (i.e., the EFSA, WHO the UK EVM, and the IOM), no negative effects of high-dose $\mathrm{VK}\left(\mathrm{K}_{1}\right.$ and $\left.\mathrm{K}_{2}\right)$ intake on animals and human beings have been found yet according to the current studies (109-113). In 2006, Ohsaki et al. (114) revealed that VK inhibited the production of IL- 6 in human macrophagic THP-1 cells and that dietary supplementation of $K_{1}$ inhibited the lipopolysaccharide (LPS)-induced inflammatory process in rats. In another in vivo and in vitro study, Ohsaki et al. further demonstrated that MK-4 exerts its effect of anti-inflammation via inhibiting the activation of $\mathrm{NF \kappa B}$ by repressing $\mathrm{IKK} \alpha / \beta$ phosphorylation (115). In 2016, Shiraishi et al. (16) reported that VK-deficient conditions exacerbated murine DSS colitis and that supplementation of MK-4 played an immunosuppressive role by inhibiting inflammatory cytokine production in CD19 (+) cells, for example, IL-6 and IL-10, ameliorating shorter colon length, body weight loss, and histological scores. On the other hand, a recent in vitro study revealed that synthetic VK $\left(\mathrm{K}_{3}\right.$ and $\mathrm{K}_{4}$ ) rather than $\mathrm{K}_{1}$ and $\mathrm{K}_{2}$ inhibits NLRP3 inflammasome activation induced by LPS independent of the coenzyme activity and targets to block interaction between NLRP3 and ASC, hence inhibiting inflammation (116). However, the role of synthetic VK as NLRP3 inhibitor had not been verified in vivo, and questions on how VK blocks the NLRPS-ASC interaction and why $\mathrm{K}_{2}$ which could be converted from $\mathrm{K}_{3}$ showed no effect on activation NLRP3 inflammasome need further investigation. Although these results preliminarily demonstrated that VK had anti-inflammatory properties, huge knowledge gaps remain regarding the immunopathological effect of VK in IBD.

In vitro and in vivo experiments revealed that $\mathrm{VK}$ inhibited the production of pro-inflammatory cytokines, especially IL-6 and tumor necrosis factor-alpha (TNF- $\alpha)(114,117)$. Administration of MK-7 showed preventive effects by suppressing CRC-risk microorganisms and metabolites (shortchain fatty acids, SCFAs), promoting serum adiponectin level, stimulating the VDR expression to trigger different antiinflammatory and anti-tumorigenic pathways (15). $\mathrm{K}_{3}$, rather than $K_{1}$ and $K_{2}$, was reported to induce DNA damage in HT-29 human CRC cells (118). Another report showed that $\mathrm{K}_{2}, \mathrm{~K}_{3}$, and $\mathrm{K}_{5}$ had efficient antitumor roles in CRC in vivo and in vitro by causing caspase-dependent apoptotic death of tumor cells (17). Supplemented VK played a safeguarding role against DSSinduced colitis and improved gut injury by suppressing inflammatory cytokine production, which could be a promising treatment target for IBDs (16). VK, as described earlier, was found to repress CRC in intensive preclinical studies. VK supplementation or deficiency, and even different sources of VK, deeply affects the intestinal status in humans and animals in vivo and in vitro (Table 1). Nevertheless, further studies are still required, for example, to elucidate the most effective form of VK and verify the clinical antitumor function of VK.

\section{Interaction Between VK and Intestinal Microbiota as well as Microbial Metabolites}

Accumulating evidence links the altered microbiota composition with the pathophysiology of IBDs $(123,124)$. Bacteria exert critical effects on the onset and perpetuation of gut inflammation in IBDs (125). The intestinal microorganism or bacteria present in food may produce bacterially synthesized menaquinones which contribute to $\mathrm{K}_{2}$ requirements in human (126). Small-intestinal bacterial overgrowth (SIBO), associated with low circulating levels of $\mathrm{K}_{2}(127)$, is involved in increased plasma levels of inactive MGP and results in alteration of $\mathrm{K}_{2}$ metabolism (128). SIBO may not increase bacterial $\mathrm{K}_{2}$ biosynthesis in the intestine but enhance dietary $\mathrm{K}_{1}$ absorption through the potentially damaged intestinal mucosa (127).The diversity of the gut microbiota was notably lower, and Lachnospiraceae and Ruminococcaceae greatly reduced in the VK-deficient group compared with the VK-normal group in a previous study (129). Compared with the VK-deficient group, supplemented with MK-4 and MK-9, reduced the relative abundance of cecal Bacteroides and Ruminococcus_1 while increased that of Lactobacillus at the genus level (130). 
TABLE 1 | Effects of different sources of VK on intestinal homeostasis (without bacteria information) of patients or animals in vivo and in vitro.

\begin{tabular}{|c|c|c|c|c|c|}
\hline VK resources & $\begin{array}{l}\text { Supplemented } \\
\text { dosage }\end{array}$ & Subjects & Results & Effects & References \\
\hline \multicolumn{6}{|l|}{ In vivo } \\
\hline MK-7 & $50 \mathrm{mg} \mathrm{kg}^{-1}$ diet & $\begin{array}{l}\text { C57BL/6J mice } \\
\text { with DSS }\end{array}$ & $\begin{array}{l}\text { Colon carcinogenesis } \downarrow \\
\text { Expression of CLCN4, p-AMVK } 1 \text {, and } \\
\text { VDR } \uparrow \\
\text { The secretion of caecum butyric acid } \\
\text { and acetic acid } \uparrow\end{array}$ & $\begin{array}{l}\mathrm{K}_{2} \text { can inhibit gut-risk microbes and increase } \\
\text { beneficial microbial metabolites to reduce colonic } \\
\text { tumor development in mice }\end{array}$ & $\begin{array}{l}\text { Zhang et al. } \\
\text { (15) }\end{array}$ \\
\hline $\mathrm{K}_{1}$ or $\mathrm{MK}-4$ & $600 \mathrm{mg} \mathrm{kg}^{-1}$ diet & $\begin{array}{l}\text { Sprague-Dawley } \\
\text { rats }\end{array}$ & $\begin{array}{l}\text { IAP activity in five intestinal segments } \\
\text { in both } K_{1} \text { and } \\
\text { MK- } 4 \text { increased } \uparrow\end{array}$ & Both $\mathrm{K}_{1}$ and $\mathrm{K}_{2}$ can enhance IAP activity & $\begin{array}{l}\text { Sogabe } \\
\text { et al. (119) }\end{array}$ \\
\hline $\mathrm{K}_{1}$ and $\mathrm{K}_{2}$ & $3 \mathrm{mg} \mathrm{kg}^{-1}$ mouse & ICR strain mice & $\begin{array}{l}\text { In the MK groups, the levels of ALP } \\
\text { activity in the jejunum } \uparrow \\
\text { IAP mRNA expression in the jejunum } \\
\text { in both } \mathrm{K}_{1} \text { and } \mathrm{K}_{2} \text { groups } \uparrow \\
\text { The expression of pregnane } \mathrm{X} \\
\text { receptor mRNA } \uparrow\end{array}$ & $\begin{array}{l}\text { Oral administration of VK enhanced IAP mRNA } \\
\text { expression }\end{array}$ & $\begin{array}{l}\text { Haraikawa } \\
\text { et al. (120) }\end{array}$ \\
\hline VK & $3.02 \mathrm{mg} \mathrm{kg}^{-1}$ diet & Juvenile Jian carp & $\begin{array}{l}\text { Malondialdehyde and protein } \\
\text { carbonyl contents } \downarrow \\
\text { AHR, ASA, SOD, CAT, GST, GSH-Px, } \\
\text { GR, activities and GSH contents in } \\
\text { the hepatopancreas and intestine } \uparrow\end{array}$ & $\begin{array}{l}\text { VK improved fish growth, digestive and } \\
\text { absorptive ability, and antioxidant capacity. }\end{array}$ & $\begin{array}{l}\text { Yuan et al. } \\
(45)\end{array}$ \\
\hline $\begin{array}{l}\text { Intravenous } \\
\text { administration } \\
\text { of } \mathrm{K}_{2}, \mathrm{~K}_{3} \text {, and } \\
\mathrm{K}_{5}\end{array}$ & $100 \mathrm{mM}$ & $\begin{array}{l}\text { 80-week-old male } \\
\text { BALB/c mice }\end{array}$ & $\begin{array}{l}\text { Tumor growth } \downarrow \\
\text { The number of apoptotic tumor cells } \uparrow\end{array}$ & $\begin{array}{l}\mathrm{K}_{2}, \mathrm{~K}_{3} \text {, and } \mathrm{K}_{5} \text { played effective antitumor effects } \\
\text { on } \mathrm{CRC} \text { by inducing caspase-dependent } \\
\text { apoptotic death of tumor cells. }\end{array}$ & $\begin{array}{l}\text { Ogawa } \\
\text { et al. (17) }\end{array}$ \\
\hline Low $\mathrm{K}_{1}$ & $\begin{array}{l}52 \text { (control), 16, 28, } \\
36,49 \mu \mathrm{kg}^{-1} \text { diet }\end{array}$ & Wistar rat & $\begin{array}{l}\text { Liver } \mathrm{K}_{1} \text { increased with the increasing } \\
\mathrm{K}_{1} \text { content in diet. } \uparrow \\
\text { Concentration of coagulation factors } \\
\text { (factor II, factor } \mathrm{V} \text {, factor } \mathrm{VII} \text {, factor IX, } \\
\text { factor } \mathrm{X} \text { ) in plasma. } \uparrow \\
\text { Prothrombin clotting time }(\mathrm{s}) \downarrow \\
\text { Cecal } \mathrm{pH} \downarrow \\
\text { Cecal wt (g), content } \mathrm{DM}\left(\mathrm{g} \mathrm{kg}^{-1}\right) \uparrow \\
\text { Butyrate } \uparrow \\
\text { Propionate, isobutyrate, isovalerate }\end{array}$ & $\begin{array}{l}\text { The potential VK supply from enteric bacterial } \\
\text { menaquinones may be altered by modifying diet } \\
\text { via altering the density of menaquinone-producing } \\
\text { microflora in large intestine. }\end{array}$ & $\begin{array}{l}\text { Mathers } \\
\text { et al. (121) }\end{array}$ \\
\hline $\mathrm{K}_{2}, \mathrm{~K}_{3}, \mathrm{~K}_{5}$ & $10 \mathrm{mM}$ & $\begin{array}{l}\text { Colon 26, } \\
\text { metastatic murine } \\
\text { CRC cell line }\end{array}$ & Enzymatic activity of caspase- $3 \uparrow$ & $\begin{array}{l}\mathrm{K}_{2}, \mathrm{~K}_{3} \text {, and } \mathrm{K}_{5} \text { induced apoptotic death of colon } \\
26 \text { cells }\end{array}$ & $\begin{array}{l}\text { Ogawa } \\
\text { et al. (17) }\end{array}$ \\
\hline $\mathrm{K}_{1}, \mathrm{~K}_{2}$ & $\begin{array}{l}200,400,600,700 \\
800 \mu \mathrm{M} \mathrm{K} \mathrm{K}_{2} ; 250,300 \\
400,500,600 \mu \mathrm{M} \mathrm{K}_{1}\end{array}$ & $\begin{array}{l}\text { HT-29, human } \\
\text { colon carcinoma } \\
\text { cells }\end{array}$ & $\begin{array}{l}\mathrm{K}_{3} \text { caused significant DNA damage at } \\
\text { low concentrations }(25-200 \mu \mathrm{M}) \text { with } \\
\text { a linear correlation of } \mathrm{r} 0.95\end{array}$ & $\begin{array}{l}K_{3} \text {, but not } K_{2} \text { and } K_{1} \text {, induced DNA damage in } \\
\text { HT-29 human CRC cells }\end{array}$ & $\begin{array}{l}\text { D'Odorico } \\
\text { et al. (118) }\end{array}$ \\
\hline MK-4 & $\begin{array}{l}0,1.0,5.0 \text {, and } 10.0 \\
\mu \mathrm{M}\end{array}$ & Caco-2 cells & $\begin{array}{l}\text { The ALP activities } \uparrow \\
\text { Expressions of human intestinal ALP } \\
\text { and SI } \uparrow\end{array}$ & $\begin{array}{l}\mathrm{K}_{2} \text { enhanced the level of ALP mRNA expression } \\
\text { in human Caco- } 2 \text { cells }\end{array}$ & $\begin{array}{l}\text { Noda et al. } \\
(46)\end{array}$ \\
\hline $\mathrm{K}_{1}$ & $\begin{array}{l}10,50,100 \text { and } 200 \\
\mu \mathrm{M}\end{array}$ & $\begin{array}{l}\text { Human colon } \\
\text { cancer cells } \\
\text { (Caco-2, HT-29, } \\
\text { SW480) }\end{array}$ & $\begin{array}{l}\text { Caused inhibition of proliferation } \\
\text { Induced apoptosis and the cell cycle } \\
\text { arrest } \\
\text { Enhanced the probiotic anti- } \\
\text { proliferative effect in a dose- } \\
\text { dependent manner } \uparrow\end{array}$ & $\begin{array}{l}\mathrm{K}_{1} \text { has enhanced anti-proliferative efficacy to } \\
\text { inhibit cancer growth }\end{array}$ & $\begin{array}{l}\text { Orlando } \\
\text { et al. (122) }\end{array}$ \\
\hline $\begin{array}{l}\mathrm{K}_{1}, \mathrm{~K}_{2}, \mathrm{~K}_{3} \text { and } \\
\mathrm{K}_{4}\end{array}$ & $\begin{array}{l}5,10 \mu \mathrm{M} \text { for } \mathrm{K}_{1} \text { and } \\
\mathrm{K}_{2} ; 1-5 \mu \mathrm{M} \text { for } \mathrm{K}_{3} \text { and } \\
\mathrm{K}_{4}\end{array}$ & $\begin{array}{l}\text { Bone marrow- } \\
\text { derived } \\
\text { macrophages }\end{array}$ & $\begin{array}{l}\text { IL- } 1 \beta \downarrow \\
\text { TNF- } \alpha \downarrow \\
\text { NLRP3 inflammasome activation } \downarrow \\
\mathrm{K}_{3} \text { and } \mathrm{K}_{4} \text { inhibit inflammation by } \\
\text { inactivating the NLRP3 inflammasome }\end{array}$ & & $\begin{array}{l}\text { Zheng et al. } \\
(116)\end{array}$ \\
\hline
\end{tabular}

AHR, anti-hydroxyl radical; ASA, anti-superoxide anion; CAT, catalase; DSS dextran sodium sulfate; IL, interleukin; CLCN4, chloride channel-4; GR, glutathione reductase; GST, glutathione-S-transferase; GSH-Px, glutathione peroxidase; GSH, glutathione; LPS, lipopolysaccharide; SI, sucrase-isomaltase; SOD, superoxide dismutase.

$\uparrow$ means increase or upregulate; $\downarrow$ represents decrease or downregulate. 
Warfarin induced intestinal dysbiosis involving VK-expressing bacteria, which was related to the expression of VKOR (131). Lactobacilli exerted a pivotal part in modulating microorganisms and maintaining a microecological balance in the intestine, producing bacteriocin-like substances to suppress the overgrowth of potentially pathogenic bacteria (132). E. coli in the gut was known as a pathogenic bacterium with the possibility of causing enteric infection (133), while another pathogenic bacterium Aeromonas was associated with gastroenteritis (134). In fish, increasing levels of VK up to $3.02 \mathrm{mg} / \mathrm{kg}$ diet could enhance Lactobacillus (LB) but decrease Aeromonas and E. coli replications (45). The potency of VK has been proven to optimize the gut microorganisms by increasing the numbers of LB and lowering the number of Aeromonas and E. coli. In another study on rat gut, a low $\mathrm{K}_{1}$ level reduced the counts of health-promoting bacteria, such as Bacteroides fragilis and B. vulgatus, and enhanced the counts of pathogenic bacteria, such as Fusobacterium, Bifidobacterium, and Enterococci, in rat feces (121). In vitro, VK ameliorated the growth of the probiotics, for example, Bifidobacterium (135). Previous studies demonstrated that MK-7 (50 mg/kg diet) supplementation alleviated colon cancer in mice by reducing representative colonic polyps and the number of large colon tumors. The VK supplementation was effective in the enrichment of Proteobacteria counts, such as promoting the relative abundance of $C$. lanceolatus, P. phenylpyruvicus, and Parasutterella excrementihominis and reducing CRC-risk microbes, such as $H$. mesocricetorum and $H$. apodemus (15). Nonetheless, debates on whether all types of VK have the same beneficial effect on intestinal microbiota are ongoing (Table 2). Regarding the beneficial effect of VK on intestinal microflora, Ponziani et al. (128) proposed that $\mathrm{K}_{2}$ intake could be prescribed in clinical practice as additional preventive measures for screening SIBO and intestinal decontamination.
Gut microbe has a variety of intestinal functions such as improving the mucosal immune system, defending against pathogens, synthesizing amino acids/vitamins, and absorbing complex macromolecules (136). Speculation on the possible underlying mechanism by which VK affects the intestinal microbiome is based on the fact that anaerobically growing bacteria, the facultatively aerobic bacteria, and most Grampositive bacteria use $\mathrm{MK}$ as the sole quinone in their oxidative and photosynthetic electron transport system (137). MK inhibitors showed selective toxicity to these bacteria without any side effects due to its exclusiveness. Although VK has a toxic effect on some bacteria unrelated to the gut, the underlying mechanism of VK in the gut microflora has not been elucidated. Hence, further in vitro and in vivo investigations in the intestine are essential.

What is more, VK can alleviate IBDs by regulating microbial metabolite (SCFA) production. Microbial MK-7 could enhance the secretion of cecum acetic acid and butyric acid (15). With the increase in the $K_{1}$ level in diet, concentrations of butyrate are enhanced and propionate, isobutyrate, and isovalerate are reduced (121). Except being used preferentially as an energy source by the enterocytes (138), microbial butyrate has the potential function to the restoration of the barrier function in IBD (139), imprint an antimicrobial program of macrophages (140), attenuate pathobiont-induced hyperinflammation (141). Propionate, capable of histone deacetylase (HDAC) inhibition, can potentiate de novo Treg-cell generation in the periphery (142). Acetate could promote intestinal IgA responses (143). Alterations in SCFA metabolism, particularly butyrate, occur in IBD (144). UC patients and healthy individuals have different compositions of the fecal microbiota, showing that butyrateproducing bacteria, $R$ hominis and $F$ prausnitzii, are reduced in

TABLE 2 | Profile of gut microbiota after supplementation or deficiency of VK in vivo and effect of VK on microflora in vitro.

\begin{tabular}{|c|c|c|c|c|}
\hline VK resources & Content of VK & Subjects & Microorganisms & References \\
\hline \multicolumn{5}{|l|}{ In vivo } \\
\hline VK-deficient & Deficient & CD patients & Ruminococcaceae, Lachnospiraceae $\downarrow$ & $\begin{array}{l}\text { Wagatsuma } \\
\text { et al. (129) }\end{array}$ \\
\hline $\begin{array}{l}\text { VK-deficient or } \\
\text { supplemented }\end{array}$ & $\begin{array}{l}\text { VK-deficient or supplemented with } 5 \\
\mu \mathrm{mol} \mathrm{kg}{ }^{-1} \mathrm{PK}, \mathrm{MK}-4, \mathrm{MK}-7 \text {, or an } \\
\text { equimolar combination of } \mathrm{PK}, \mathrm{MK}-4 \text {, } \\
\text { MK-7 }\end{array}$ & $\begin{array}{l}\text { Female mice of C57 } \\
\text { BL } 6 \mathrm{~J}\end{array}$ & $\begin{array}{l}\text { The VK-deficient group had the lowest relative abundance of } \\
\text { Lactobacillus, and the greatest relative abundances of } \\
\text { Bacteroides and a Ruminococcus genus group } \\
\text { (Ruminococcus_1). }\end{array}$ & $\begin{array}{l}\text { Ellis et al. } \\
(130)\end{array}$ \\
\hline VK & $3.02 \mathrm{mg} \mathrm{kg}^{-1}$ & Juvenile Jian carp & $\begin{array}{l}\text { LB } \uparrow \\
\text { Aeromonas, E. coli } \downarrow\end{array}$ & $\begin{array}{l}\text { Yuan et al. } \\
(45)\end{array}$ \\
\hline Low $\mathrm{K}_{1}$ & 52 (control), 16, 28, 36, $49 \mu \mathrm{g} \mathrm{kg}^{-1}$ diet & Wistar rat & $\begin{array}{l}\text { Bacteroides fragilis, Bacteroides vulgatus } \downarrow \\
\text { Fusobacterium, Bifidobacterium, Enterococci } \uparrow\end{array}$ & $\begin{array}{l}\text { Mathers } \\
\text { et al. (121) }\end{array}$ \\
\hline MK-7 & $50 \mathrm{mg} \mathrm{kg}^{-1}$ diet & Mouse & $\begin{array}{l}\text { C. lanceolatus, P. phenylpyruvicus, and Parasutterella } \\
\text { excrementihominis } \uparrow \\
\text { H. mesocricetorum and H. apodemus } \downarrow\end{array}$ & $\begin{array}{l}\text { Zhang et al. } \\
\text { (15) }\end{array}$ \\
\hline $\begin{array}{l}\text { Diet supplemented } \\
\text { with black-eye } \\
\text { beans or white rice } \\
\text { In vitro }\end{array}$ & $\begin{array}{l}\text { Black-eye beans }\left(108 \mu \mathrm{g} \mathrm{kg}^{-1} \mathrm{~K}_{1}\right) \text { vs. } \\
\text { white rice }\left(2 \mu \mathrm{g} \mathrm{kg} \mathrm{K}_{1}\right)\end{array}$ & Rat & $\begin{array}{l}\text { Total Bacteroides, Bacteroides fragilis, Bacteroides vulgatus, } \\
\text { Veilonella sp. } \uparrow \\
\text { Fusobacterium sp., Anaerobic Gram-positive rods } \downarrow\end{array}$ & $\begin{array}{l}\text { Mathers } \\
\text { et al. (121) }\end{array}$ \\
\hline MK-4 or MK-7 & $5 \mu \mathrm{g} \mathrm{ml}^{-1}$ & $\begin{array}{l}\text { Bacteria were } \\
\text { isolated from } \\
\text { periodontally healthy } \\
\text { subjects. }\end{array}$ & Bifidobacterium, Porphyromonas gingiva $\uparrow$ & $\begin{array}{l}\text { Hojo et al. } \\
(135)\end{array}$ \\
\hline
\end{tabular}

$\uparrow$ means increase or upregulate; $\downarrow$ represents decrease or downregulate. 
UC (145). Moreover, UC has less obvious reduced butyratesynthetic capacity of the microbiota than UC (144), while the clear relationship among $\mathrm{VK}$, butyrate-producing bacteria, and butyrate remains unknown. Also, further studies trying to explain this detailed mechanism will be necessary and interesting.

\section{VK Against Oxidation}

IBDs are associated with a disequilibrium between reactive oxygen species (ROS) and antioxidant response, giving rise to oxidative stress (146). Oxidative stress is a crucial cause in the pathophysiological process of certain chronic diseases, resulting from an imbalance between pro- and antioxidant substances (147), resulting in potential cellular damage and dysfunction (148). Several studies demonstrated oxidative stress as an important factor in the pathogenesis, progression, and severity of IBDs (146) and showed that the use of prophylactics to inhibit oxidative stress improved the health status of patients $(149,150)$. VK showed its ability to alleviate intestinal oxidative stress via regulating the expression of pro-oxidant and antioxidant enzymes $(45,151,152)$.

Yuan et al. (45) conducted in vivo studies using dietary VK ( $3.13 \mathrm{mg} / \mathrm{kg}$ diet) to improve the antioxidant capabilities of digestive organs by decreasing the contents of protein carbonyl and malondialdehyde (MDA) and improving anti-hydroxyl radical (AHR), anti-superoxide anion (ASA), superoxide dismutase (SOD), glutathione $(\mathrm{GSH})$, glutathione peroxidase (GSH-Px), glutathione-S-transferase (GST), catalase (CAT), and glutathione reductase (GR) activities and contents in the intestine. Nevertheless, this was a study conducted on the carp, which could not be simply extrapolated to mammals. More investigations in mammals should be performed in the future to verify the effect and mechanism of $\mathrm{VK}$ on related oxidoreductase activity in the intestine.

In in vitro studies, VK has antecedently been reported to possess free radical-scavenging activity when assayed in non-aqueous solvents (153). Studies of cell lines outside of the intestinal cells showed that the biological activity of MK-4 dose-dependently suppressed the upregulation in the expression of iNOS, COX-2, p38 activation, NF- $\mathrm{KB}, \mathrm{ROS}$, and caspase-1 activation (4) and prevented ROS from inducing oxidative damage via inactivating the p38 MAP kinase pathway $(3,154,155)$. The disproportionate accumulation of ROS might, however, alter several cellular proteins and upregulate pro-inflammatory cytokines, further downregulating the expression of $\mathrm{TJ}$ proteins and triggering the deterioration of the intestinal permeability (156). It was speculated that VK might exert the same ability to prevent oxidative damage in intestinal cells in vivo, which needs empirical studies for validation. However, the mechanism underlying the VK protective function remains unclear to date. Thus, further analysis of its antioxidant functions in the intestine is necessary.

\section{VK Contributes to Blood Coagulation in Gastrointestinal Disease}

GIB, due to peptic ulcer, colitis, hemorrhoids, cancer, malignancy, esophageal varices, or other conditions, occurs from upper and lower GIB (157). VK deficiency in newborns also results in massive GIB (158). Besides, GIB is a frequent and potentially serious complication of oral anticoagulant (159). The risk of GIB and subsequent complications is considerably lower for patients on non-VK antagonist oral anticoagulants (NOACs) than for patients on warfarin (160). The case fatality proportion is nearly $10 \%$ and $3 \%$ for hemorrhage of the upper and lower gastrointestinal tracts, respectively $(161,162)$. The rapid onset of VK deficiency in patients occurs may be due to a combination of major abdominal surgery in patients who are receiving antibiotics and poor food intake (163). GIB due to VK deficiency in patients on antibiotics usually stopped by timely injections of VK (47).

\section{VK and Gut Epithelial Development}

Nutrient availability is closely involved in digestive and absorptive ability, which depends on the growth and development of the pancreas and intestine, and the activities of digestive enzymes such as amylase, lipase, and protease, and gut enzymes, such as IAP and sucrase-isomaltase (SI) (164). IAP, a brush-border protein, is a defense factor in the gut mucosa (165) and an intestinal crypt-villus differentiation marker at the brush border of gut epithelial cells that can detoxify LPS by dephosphorylation $(46,166)$. SI is a brush border enzyme of small bowel to metabolize sucrose, whose deficient condition causes symptoms of maldigestion syndromes including diarrhea, bloating, abdominal pain, and gas (167). In vitro, $\mathrm{K}_{2}$ enhances IAP and the expression of SI and may enhance the cellular differentiation and functions of Caco-2 cells (46). In vivo, dietary $\mathrm{K}_{1}$ or $\mathrm{K}_{2}(3 \mathrm{mg} / \mathrm{kg}$ mouse) supplementation enhances the activity and mRNA expression of IAP in rats and mice $(119,120)$. Both $K_{1}$ and $K_{2}(600 \mathrm{mg} / \mathrm{kg}$ diet $)$ exhibited increased IAP activity in each segment of the small intestine when the small intestine of Sprague-Dawley rats was divided into five segments (119). A study proved that VK increased the IAP activity (119) by the steroid and xenobiotic receptor (SXR) in a rat model (168). MK4 is a ligand for SXR (known as its murine ortholog, pregnane $\mathrm{X}$ receptor, PXR) (168-170), and PXR is abundantly expressed in the intestine and liver in mammals (171); its activation suppresses the NFKB signal pathway and relieves the severity of IBD, indicating the fundamental role for PXR in IBD treatment $(172,173)$. It could be speculated that VK may exert a positive role in gut via PXR.

VDR, regulating $1 \alpha, 25$-dihydroxy vitamin D3 $[1,25(\mathrm{OH})$ 2D3], is richly expressed in the small bowel and colon (174), while its expression decreases in both UC and CD patients (175) and downregulated by TNF- $\alpha$ associated with IBD (176). VDR deficiency in the gut leads to abnormal paneth cells and impaired autophagy function, imbalance of autophagy and apoptosis in the intestinal epithelium (177), change in the function of microbiome (178), enhancement of $\mathrm{Wnt} / \beta$-catenin signaling, and tumor burden (179). Gut VDR exerts significantly regulatory effects on immunity, anti-inflammation, cell proliferation, autophagy activation, differentiation, barrier function and permeability, and host-microbial interactions (180, 181). VK deficiency significantly increases the VDR binding to DNA and that binding was sharply reduced when gut endogenous containing VDR undergo VK-dependent 
gamma-carboxylation (182). In the presence of $\mathrm{K}_{1}$, VDR can undergo $\gamma$-carboxylation in vitro and that $15 \%-25 \%$ of Glu residues in the VDR are carboxylated in vivo (183). AMPK is also known to improve epithelial differentiation and barrier function, integrity, and ultrastructure of tight junction in the gut $(184,185)$. Vitamin D3 and the AMPK agonist metformin were observed to play synergistic preventive roles against colon cancer (186). MK-7 was found to stimulate VDR and AMPK expression effectively (15). MK-7 may have indirect potential clinical application in preventing and treating IBD by vitamin $\mathrm{D} /$ VDR and AMPK signaling.

$\mathrm{ADPN}$ is an adipocytokine, exerting anti-carcinogenic roles in colon tumorigenesis $(187,188)$, confirmed as a potential and promising target for CRC therapy for its anti-tumorigenic effects (189, 190). However, MK-7 interventions can elevate the expression of ADPN in rats with CRC (15). To date, emerging studies suggested substantial beneficial effects of VK on intestinal growth and function by mediating the activity and mRNA expression of IAP, ADPN, VDR, and AMPK signaling.

Even though a few studies showed promoting roles of gut epithelial development of VK, indicating potential preventive and therapeutic effects of CRC, a body of animal experiments and cell tests is in urgent need.

\section{VK Exerts Gastroprotection Role via Related VKDPs}

VK is an essential cofactor of GGCX for the posttranslational conversion of peptide-bound Glu to Gla (54). VKDPs are known to be a functional protein family with Gla residues, which result from a $\gamma$-carboxylation of Glu residues and a posttranslation modification dependent of VK, and catalyzed by $\gamma$ glutamylcarboxylase (191-193) (Figure 4). After carboxylation, the propeptide which is essential for Gla proteins binding to the vitamin-K-dependent carboxylase is removed and the mature protein is secreted $(42,194)$. Among 17 kinds of recognized $\gamma$ carboxylated proteins, the biofunction of VKDPs in the intestine, such as protein C (195), protein S (196), Gas 6 (197), and MGP (198), is another speculated mechanism through which VK might relieve symptoms of gastrointestinal disease.

Thromboembolism is caused by an imbalance of procoagulant, anticoagulant, and fibrinolytic factors (199). It is an extra-intestinal manifestation and a crucial cause of morbidity and mortality in IBD (200). IBD in hypercoagulability is mainly manifested as microthrombus formation and microcirculation disorder (201), and the thrombus formation rate is between $1.2 \%$ and $7.1 \%$ (202). Protein C (PC), synthesized by the liver, is a vitamin-Kdependent glycoprotein and a natural anticoagulant protein. The PC system, playing crucial roles in anticoagulation and inflammation, is a novel participant in the pathogenesis of acute and chronic inflammatory diseases, such as IBDs (203). The defective PC pathway in both inactive and non-active diseases may result in hypercoagulability in IBD, which is associated with both the inflammatory process and disturbances in the anticoagulant system (204). In the UC mouse, the PC system is inhibited via the secretion of cytokines from macrophages, subsequently influencing the function of endothelial cells (195), while it could be reversed by blocking CXCR4 (205). In addition to its anticoagulant activity, the PC pathway, acting on the endothelial compartment and controlling gut homeostasis by reducing cytokine production and inhibiting leukocyte adhesion (206, 207), exerts cytoprotective effects in the gut $(207,208)$. Consequently, activated PC treatment can diminish weight loss $(206,207)$, reduce the disease activity index (207), relieve the pathological lesions (206), and reduce histological colitis scores (207). However, functionally inactive molecules of VKDPs are produced at their site of synthesis and released into the bloodstream when the supply of VK is deficient or abnormal (209). VK supplementation therapy might become a new direction in the pathogenesis and treatment of IBD via the activated PC pathway, and this speculation needs scientific experimental verification.

Protein S, a well-defined VK-dependent cofactor for activated protein $\mathrm{C}$, exists in a free anticoagulantly active form and in an inactive form complexed to $\mathrm{C} 4 \mathrm{~b}$-binding protein in normal adult plasma (210). Protein S can activate TAM receptors (Tyro3, Axl, and Mer) which have important effects on hemostasis and inflammation (211). It is found that the impairment of the protein S/protein $\mathrm{C} /$ thrombomodulin system in $\mathrm{CD}$ patients contributes to coagulation and might be vital for both the development of $\mathrm{CD}$ and its thromboembolic complications (196), while CD is mediated by multifocal gastrointestinal infarction (212) which is due to thrombosis in small vessels (196). Free plasma protein S levels are slightly but significantly decreased in IBD patients (213). Consequently, low Protein S levels are considered as a potential etiologic factor in patients with IBD and recurrent deep venous thrombosis (DVT) (214).

Gas 6 is a $\gamma$-carboxyglutamic acid domain-containing protein and a VK-dependent growth factor for mesangial and epithelial cells (215), which shares $43 \%$ amino acid identity with protein S. Gas6 is another VKDP activator of TAM receptors (211). It suppresses the production of TNF- $\alpha$ which is an inflammatory cytokine induced by TLR 3, 4, and 9 via activating TAM receptors (216). In patients with advanced colorectal cancer, the immunoreactivity of Gas6 in cancer tissues was positively associated with prognosis (197). Gas6 suppresses the progression of intestinal tumors induced by DSS correlated with inhibition of stromal immune reactions in vivo (197). In a great scale of human gastric cancer tissue and cell lines, there is a high expression of mRNA and protein of Gas6 (217). With recombinant Gas6 and a decoy receptor of Axl in vitro, the Gas6-Axl signaling pathway improved invasion and inhibited apoptosis via the Akt signaling pathway (217).

MGP is a kind of secreted protein, also a small Gla VKDP, and acts as a powerful naturally occurring inhibitor of calcification and has strong affinity for calcium ions (218). Its inactive form, dephosphorylated-uncarboxylated MGP (dp-ucMGP), has been regarded as one of the best markers representing low $\mathrm{K}_{2}$ status (219). MGP has to undergo VK-dependent carboxylation and phosphorylation to become biologically active (220). Consequently, VK deficiency leads to the inactive dp-ucMGP (220). Experimental data of a cross-sectional study in UC and CD patients support the immunomodulatory effect of MGP in IBD and involvement in the pathophysiology of the disease (221). Compared 


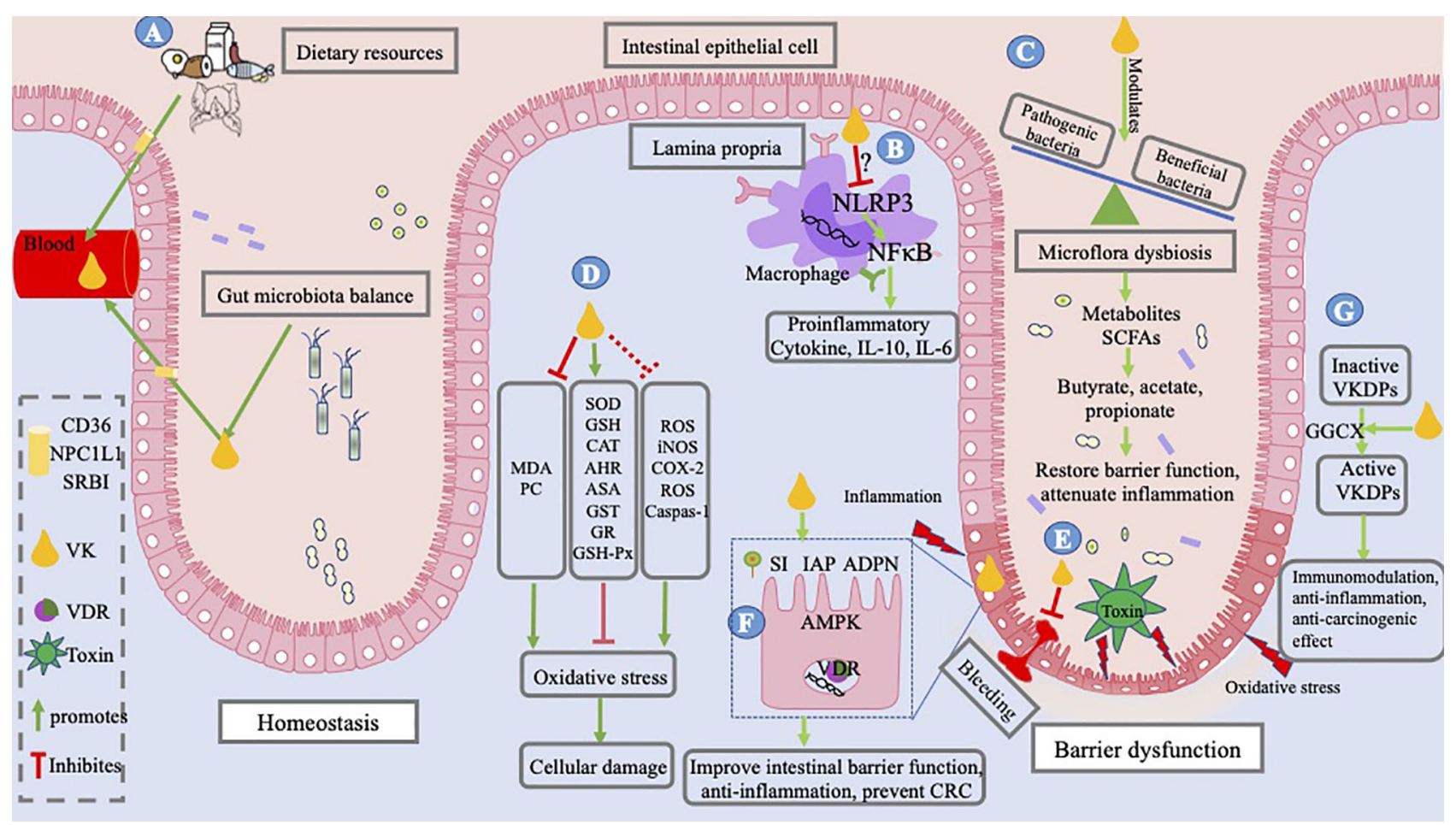

FIGURE 5 | Mechanism underlying IBD and role of VK. IBD occurs as a result of altered interactions between the mucosal immune system and gut bacteria, resulting in bleeding, an imbalance between pro- and antioxidant substances, and barrier dysfunction. Toxins released by pathogenic bacteria; oxidative stress caused by oxidizers, that is, MDA, PC, and ROS; and pro-inflammatory factors induce barrier dysfunction. (A) VK in the body, coming from dietary resources and bacterial sources, is absorbed into the intestinal lumen; it is absorbed by small-intestinal enterocytes through the NPCIL1 protein, SR-BI, and CD 36. VK exerts a gut-protective role by alleviating intestinal inflammation and oxidation, optimizing intestinal microflora, and improving key biological enzymes in the intestine. (B) It may achieve an immunosuppressive function by inhibiting NLRP3 activation, thereby decreasing the inflammatory cytokine production, for example, IL-6, IL-10, and TNF$\alpha$. (C) VK modulates the profile of gut bacteria by inhibiting pathogenic bacteria and upregulating beneficial bacteria, thus reducing the production of toxins and regulating microbial metabolites. (D) VK is reported to alleviate oxidative stress and cellular damage by decreasing the levels of MDA and PC and increasing the levels of SOD, GSH, AHR, CAT, ASA, GST, GR, and GSH-Px in vivo, while studies of preventing ROS, iNOS, COX-2, and caspase-1 in vitro of cell lines outside of the intestinal cells need verification in enterocytes. (E) VK deficiency results in GIB and VK administration can stop GIB. (F) VK enhances the biological function of the intestinal epithelial cells by increasing the expression of AMPK and VDR, and intestinal enzymes, such as IAP, SI, and ADPN. (G) VK is essential for the activation of VKDPs and exerts indirect roles of immunomodulation, anti-inflammation, and anti-carcinogenic effects via VKDPs. The figure is in a non-editable format.

to the healthy control group, plasma levels of dp-ucMGP were significantly higher in IBD patients and positively correlated with high sensitivity C-reactive protein (hsCRP) levels (221). The expression of MGP, which can be upregulated by a conserved binding site for Egr-1 in the upstream region of the human MGP gene, was positively correlated with disease severity of UC patients and DSS-induced colitis rats (222). MGP was upregulated in different stages of colon cancer and associated with a worse prognosis (223). Endogenous MGP promotes the growth and proliferation of colon cancer cells by increasing the intracellular calcium level and activating the NF- $\kappa B$ pathway (223), while supplementation of exogenous mesenchymal stromal cell (MSC)derived MGP might be a novel important mediator of MSCmediated immunomodulation in treating $\mathrm{CD}$ by alleviating the clinical and histopathological severity of colonic inflammation in mouse experimental colitis models to a remarkable degree (198). Moreover, MSC-derived MGP alleviated the clinical and histopathological severity of colonic inflammation in mouse experimental colitis models to a remarkable degree (198).
In another report, SIBO is associated with reduced matrix Glaprotein activation (128). In vitro, MSC-derived MGP was observed to suppress cell proliferation and cytokine production in $\mathrm{T}$ cells obviously (198), and it could serve as a potential prognostic biomarker in colon cancer patients (223).

Studies analyzed above examining the association between related VKDPs and intestinal diseases do not differentiate between the total and undercarboxylated forms or take into consideration VK intake. Consequently, a great deal of studies need to investigate the relationship between $\mathrm{VK}$ and the responding effects of VKDPs on the intestine.

\section{CONCLUSIONS AND FUTURE PERSPECTIVE}

Coagulation has been the canonical function of VK since its discovery in 1936. The research and development studies during 
an over 80-year span further enhanced the benefits derived from VK. In recent years, VK has been well recognized in health and disease conditions such as type 2 diabetes mellitus, osteoporosis, $\mathrm{CKD}$, cardiovascular disease, and certain cancers. Based on the present studies and publications, the direct and indirect gastrointestinal protection effects of vitamin are summarized in Figure 5. Novel direct functions of VK are associated with alleviating intestinal inflammation and oxidation, improving intestinal microbiota, regulating microbial metabolites, and improving epithelial development in the intestine. Indirect roles of VK are involved in anti-inflammation, immunomodulation, and anti-tumorigenesis in the gut based on the presence of certain related VKDPs. In summary, the role of VK in the improvement of gut integrity has made it a potentially useful prophylactic compound for the prevention and clinical treatment of intestinal diseases, especially for IBD. Although VK may be a potential and promising treatment target for IBD, the mechanism underlying the influence of $\mathrm{VK}$ on the microbial community, immunity, intestinal

\section{REFERENCES}

1. Beulens JW, Booth SL, van den Heuvel EG, Stoecklin E, Baka A, Vermeer C. The Role of Menaquinones (Vitamin $\mathrm{K}_{2}$ ) in Human Health. Br J Nutr (2013) 110(8):1357-68. doi: 10.1017/S0007114513001013

2. Hao Z, Jin DY, Chen X, Schurgers LJ, Stafford DW, Tie JK. $\gamma$-Glutamyl Carboxylase Mutations Differentially Affect the Biological Function of Vitamin K-Dependent Proteins. Blood (2021) 137(4):533-43. doi: 10.1182/ blood.2020006329

3. Li J, Lin JC, Wang H, Peterson JW, Furie BC, Furie B, et al. Novel Role of Vitamin $\mathrm{K}$ in Preventing Oxidative Injury to Developing Oligodendrocytes and Neurons. J Neurosci (2003) 23(13):5816-26. doi: 10.1523/ JNEUROSCI.23-13-05816.2003

4. Yu YX, Li YP, Gao F, Hu QS, Zhang Y, Chen D, et al. Vitamin $\mathrm{K}_{2}$ Suppresses Rotenone-Induced Microglial Activation In Vitro. Acta Pharmacol Sin (2016) 37(9):1178-89. doi: 10.1038/aps.2016.68

5. Viegas CSB, Costa RM, Santos L, Videira PA, Silva Z, Araújo N, et al. GlaRich Protein Function as an Anti-Inflammatory Agent in Monocytes/ Macrophages: Implications for Calcification-Related Chronic Inflammatory Diseases. PloS One (2017) 12(5):e0177829. doi: 10.1371/ journal.pone.0177829

6. Kiely A, Ferland G, Ouliass B, O’Toole PW, Purtill H, O'Connor EM. Vitamin K Status and Inflammation are Associated With Cognition in Older Irish Adults. Nutr Neurosci (2020) 23(8):591-9. doi: 10.1080/ 1028415X.2018.1536411

7. Vera MC, Lorenzetti F, Lucci A, Comanzo CG, Ceballos MP, Pisani GB, et al. Vitamin $\mathrm{K}_{2}$ Supplementation Blocks the Beneficial Effects of IFN- $\alpha-2 b$ Administered on the Early Stages of Liver Cancer Development in Rats. Nutrition (2019) 59:59170-9. doi: 10.1016/j.nut.2018.08.016

8. Wang M, Chen L, Chen Y, Wei R, Guo Q, Zhu S, et al. Intracellular Matrix Gla Protein Promotes Tumor Progression by Activating JAK2/STAT5 Signaling in Gastric Cancer. Mol Oncol (2020) 14(5):1045-58. doi: 10.1002/1878-0261.12652

9. Takumi N, Shirakawa H, Ohsaki Y, Ito A, Watanabe T, Giriwono PE, et al. Dietary Vitamin K Alleviates the Reduction in Testosterone Production Induced by Lipopolysaccharide Administration in Rat Testis. Food Funct (2011) 2(7):406-11. doi: 10.1039/c1fo10058k

10. Ferland G, Vitamin K. An Emerging Nutrient in Brain Function. Biofactors (2012) 38(2):151-7. doi: 10.1002/biof.1004

11. Sakaue M, Mori N, Okazaki M, Kadowaki E, Kaneko T, Hemmi N, et al. Vitamin K has the Potential to Protect Neurons From MethylmercuryInduced Cell Death In Vitro. J Neurosci Res (2011) 89(7):1052-8. doi: $10.1002 /$ jnr.22630 barrier, and antioxidation remains unknown. Scientific research on the dose-response effects of VK may be a way forward, and longterm clinical trials are necessary for confirmation in future studies.

\section{AUTHOR CONTRIBUTIONS}

The authors' contributions were as follows. YL writes and BZ designed this review; the others were responsible for the modification and correction. All authors contributed to the article and approved the submitted version.

\section{FUNDING}

This work was supported by the National Natural Science Foundation of China (No. 32072750) and the 2115 Talent Development Program of China Agricultural University.

12. Lev M, Milford AF. Effect of Vitamin K Depletion and Restoration on Sphingolipid Metabolism in Bacteroides Melaninogenicus. J Lipid Res (1972) 13(3):364-70. doi: 10.1016/S0022-2275(20)39399-8

13. Ferland G. Vitamin K and the Nervous System: An Overview of its Actions. Adv Nutr (2012) 3(2):204-12. doi: 10.3945/an.111.001784

14. McCann A, Jeffery IB, Ouliass B, Ferland G, Fu X, Booth SL, et al. Exploratory Analysis of Covariation of Microbiota-Derived Vitamin K and Cognition in Older Adults. Am J Clin Nutr (2019) 110(6):1404-15. doi: 10.1093/ajcn/nqz220

15. Zhang Y, Ma C, Zhao J, Xu H, Hou Q, Zhang H. Lactobacillus Casei Zhang and Vitamin $\mathrm{K}_{2}$ Prevent Intestinal Tumorigenesis in Mice via AdiponectinElevated Different Signaling Pathways. Oncotarget (2017) 8(15):24719-27. doi: 10.18632/oncotarget.15791

16. Shiraishi E, Iijima H, Shinzaki S, Nakajima S, Inoue T, Hiyama S, et al. Vitamin K Deficiency Leads to Exacerbation of Murine Dextran Sulfate Sodium-Induced Colitis. J Gastroenterol (2016) 51(4):346-56. doi: 10.1007/ s00535-015-1112-x

17. Ogawa M, Nakai S, Deguchi A, Nonomura T, Masaki T, Uchida N, et al. Vitamins $\mathrm{K}_{2}, \mathrm{~K}_{3}$ and $\mathrm{K}_{5}$ Exert Antitumor Effects on Established Colorectal Cancer in Mice by Inducing Apoptotic Death of Tumor Cells. Int J Oncol (2007) 31(2):323-31. doi: 10.3892/ijo.31.2.323

18. Azuma K, Inoue S. Multiple Modes of Vitamin K Actions in Aging-Related Musculoskeletal Disorders. Int J Mol Sci (2019) 20(11):2844. doi: 10.3390/ ijms20112844

19. Rønning SB, Pedersen ME, Berg RS, Kirkhus B, Rødbotten R. Vitamin $\mathrm{K}_{2}$ Improves Proliferation and Migration of Bovine Skeletal Muscle Cells In Vitro. PloS One (2018) 13(4):e0195432. doi: 10.1371/journal.pone.0195432

20. Al-Suhaimi EA, Al-Jafary MA. Endocrine Roles of Vitamin K-DependentOsteocalcin in the Relation Between Bone Metabolism and Metabolic Disorders. Rev Endocr Metab Disord (2020) 21(1):117-25. doi: 10.1007/ s11154-019-09517-9

21. Fusaro M, Noale M, Viola V, Galli F, Tripepi G, Vajente N, et al. Vertebral Fractures, Vascular Calcifications, and Mortality: VItamin K Italian (VIKI) Dialysis Study. J Bone Miner Res (2012) 27(11):2271-8. doi: 10.1002/jbmr.1677

22. Tsugawa N, Shiraki M. Vitamin K Nutrition and Bone Health. Nutrients (2020) 12(7):1909. doi: 10.3390/nu12071909

23. Dao DT, Anez-Bustillos L, Finkelstein AM, Mitchell PD, O'Loughlin AA, Fell GL, et al. Trends of INR and Fecal Excretion of Vitamin K During Cholestasis Reversal: Implications in the Treatment of Neonates With Intestinal Failure-Associated Liver Disease. JPEN J Parenter Enteral Nutr (2020) 44(5):951-8. doi: 10.1002/jpen.1677

24. McCabe KM, Booth SL, Fu X, Shobeiri N, Pang JJ, Adams MA, et al. And Therapeutic Warfarin Alter the Susceptibility to Vascular Calcification in 
Experimental Chronic Kidney Disease. Kidney Int (2013) 83(5):835-44. doi: 10.1038/ki.2012.477

25. Kaesler N, Magdeleyns E, Herfs M, Schettgen T, Brandenburg V, Fliser D, et al. Impaired Vitamin K Recycling in Uremia is Rescued by Vitamin K Supplementation. Kidney Int (2014) 86(2):286-93. doi: 10.1038/ki.2013.530

26. Yoshida M, Jacques PF, Meigs JB, Saltzman E, Shea MK, Gundberg C, et al. Effect of Vitamin K Supplementation on Insulin Resistance in Older Men and Women. Diabetes Care (2008) 31(11):2092-6. doi: 10.2337/dc08-1204

27. Manna P, Kalita J. Beneficial Role of Vitamin K Supplementation on Insulin Sensitivity, Glucose Metabolism, and the Reduced Risk of Type 2 Diabetes: A Review. Nutrition (2016) 32(7-8):732-9. doi: 10.1016/j.nut.2016.01.011

28. Santos EAD, Giudici KV, França NAG, Peters BSE, Fisberg RM, Martini LA. Correlations Among Vitamin K Intake, Body Fat, Lipid Profile and Glucose Homeostasis in Adults and the Elderly. Arch Endocrinol Metab (2020) 64 (4):436-44. doi: 10.20945/2359-3997000000230

29. Knapen MHJ, Jardon KM, Vermeer C. Vitamin K-Induced Effects on Body Fat and Weight: Results From a 3-Year Vitamin $\mathrm{K}_{2}$ Intervention Study. Eur J Clin Nutr (2018) 72(1):136-41. doi: 10.1038/ejcn.2017.146

30. Shea MK, Booth SL, Gundberg CM, Peterson JW, Waddell C, DawsonHughes B, et al. Adulthood Obesity is Positively Associated With Adipose Tissue Concentrations of Vitamin $\mathrm{K}$ and Inversely Associated With Circulating Indicators of Vitamin K Status in Men and Women. J Nutr (2010) 140(5):1029-34. doi: 10.3945/jn.109.118380

31. Schurgers LJ, Uitto J, Reutelingsperger CP. Vitamin K-Dependent Carboxylation of Matrix Gla-Protein: A Crucial Switch to Control Ectopic Mineralization. Trends Mol Med (2013) 19(4):217-26. doi: 10.1016/ j.molmed.2012.12.008

32. Theuwissen E, Smit E, Vermeer C. The Role of Vitamin K in Soft-Tissue Calcification. Adv Nutr (2012) 3(2):166-73. doi: 10.3945/an.111.001628

33. Vlasschaert C, Goss CJ, Pilkey NG, McKeown S, Holden RM. Vitamin K Supplementation for the Prevention of Cardiovascular Disease: Where Is the Evidence? A Systematic Review of Controlled Trials. Nutrients (2020) 12 (10):2909. doi: 10.3390/nu12102909

34. Palmer CR, Blekkenhorst LC, Lewis JR, Ward NC, Schultz CJ, Hodgson JM, et al. Quantifying Dietary Vitamin K and its Link to Cardiovascular Health: A Narrative Review. Food Funct (2020) 11(4):2826-37. doi: 10.1039/ C9FO02321F

35. Kostic AD, Xavier RJ, Gevers D. The Microbiome in Inflammatory Bowel Disease: Current Status and the Future Ahead. Gastroenterology (2014) 146 (6):1489-99. doi: 10.1053/j.gastro.2014.02.009

36. Hansen JJ. Immune Responses to Intestinal Microbes in Inflammatory Bowel Diseases. Curr Allergy Asthma Rep (2015) 15(10):61. doi: 10.1007/ s11882-015-0562-9

37. Podolsky DK. Inflammatory Bowel Disease. N Engl J Med (2002) 347 (6):417-29. doi: 10.1056/NEJMra020831

38. King JA, Underwood FE, Panaccione N, Quan J, Windsor JW, Kotze PG, et al. Trends in Hospitalisation Rates for Inflammatory Bowel Disease in Western Versus Newly Industrialised Countries: A Population-Based Study of Countries in the Organisation for Economic Co-Operation and Development. Lancet Gastroenterol Hepatol (2019) 4(4):287-95. doi: 10.1016/S2468-1253(19)30013-5

39. Nadeem MS, Kumar V, Al-Abbasi FA, Kamal MA, Anwar F. Risk of Colorectal Cancer in Inflammatory Bowel Diseases. Semin Cancer Biol (2020) 64:6451-60. doi: 10.1016/j.semcancer.2019.05.001

40. Kruidenier L, Verspaget HW. Review Article: Oxidative Stress as a Pathogenic Factor in Inflammatory Bowel Disease - Radicals or Ridiculous? Aliment Pharmacol Ther (2002) 16(12):1997-2015. doi: 10.1046/j.1365-2036.2002.01378.x

41. Weisshof R, Chermesh I. Micronutrient Deficiencies in Inflammatory Bowel Disease. Curr Opin Clin Nutr Metab Care (2015) 18(6):576-81. doi: 10.1097/ MCO.0000000000000226

42. Booth SL, Centi A, Smith SR, Gundberg C. The Role of Osteocalcin in Human Glucose Metabolism: Marker or Mediator? Nat Rev Endocrinol (2013) 9(1):43-55. doi: 10.1038/nrendo.2012.201

43. Booth SL. Roles for Vitamin K Beyond Coagulation. Annu Rev Nutr (2009) 29:2989-110. doi: 10.1146/annurev-nutr-080508-141217

44. Shiraishi E, Iijima H, Araki M, Kawai S, Hiyama S, Inoue T, et al. Tu1702 Vitamin K Deficiency Deteriorates Murine DSS Colitis Through IL-6
Production From B Cells. Gastroenterology (2014) 146(5):S-822. doi: 10.1016/S0016-5085(14)62979-6

45. Yuan J, Feng L, Jiang WD, Liu Y, Jiang J, Li SH, et al. Effects of Dietary Vitamin K Levels on Growth Performance, Enzyme Activities and Antioxidant Status in the Hepatopancreas and Intestine of Juvenile Jian Carp (Cyprinus Carpiovar. Jian). Aquac Nutr (2016) 22(2):352-66. doi: 10.1111/anu.12264

46. Noda S, Yamada A, Tanabe R, Nakaoka K, Hosoi T, Goseki-Sone M. Menaquinone-4 (Vitamin $\mathrm{K}_{2}$ ) Up-Regulates Expression of Human Intestinal Alkaline Phosphatase in Caco-2 Cells. Nutr Res (2016) 36 (11):1269-76. doi: 10.1016/j.nutres.2016.10.001

47. Hooper CA, Haney BB, Stone HH. Gastrointestinal Bleeding Due to Vitamin K Deficiency in Patients on Parenteral Cefamandole. Lancet (1980) 1 (8158):39-40. doi: 10.1016/S0140-6736(80)90571-1

48. Widhalm JR, Ducluzeau AL, Buller NE, Elowsky CG, Olsen LJ, Basset GJ. Phylloquinone (Vitamin K(1)) Biosynthesis in Plants: Two Peroxisomal Thioesterases of Lactobacillales Origin Hydrolyze 1,4-Dihydroxy-2Naphthoyl-CoA. Plant J (2012) 71(2):205-15. doi: 10.1111/j.1365313X.2012.04972.x

49. Booth SL, Suttie JW. Dietary Intake and Adequacy of Vitamin K. J Nutr (1998) 128(5):785-8. doi: 10.1093/jn/128.5.785

50. Bentley R, Meganathan R. Biosynthesis of Vitamin K (Menaquinone) in Bacteria. Microbiol Rev (1982) 46(3):241-80. doi: 10.1128/mr.46.3.241280.1982

51. Halder M, Petsophonsakul P, Akbulut AC, Pavlic A, Bohan F, Anderson E, et al. Double Bonds Beyond Coagulation Insights Into Differences Between Vitamin $K_{1}$ and $K_{2}$ in Health and Disease. Int J Mol Sci (2019) 20(4):896. doi: 10.3390/ijms 20040896

52. Shea MK, Berkner KL, Ferland G, Fu X, Holden RM, Booth SL. Perspective: Evidence Before Enthusiasm-A Critical Review of the Potential Cardiovascular Benefits of Vitamin K. Adv Nutr (2021) 12(3):632-46. doi: 10.1093/advances/nmab004

53. Iwamoto J, Sato Y, Takeda T, Matsumoto H. High-Dose Vitamin K Supplementation Reduces Fracture Incidence in Postmenopausal Women: A Review of the Literature. Nutr Res (2009) 29(4):221-8. doi: 10.1016/ j.nutres.2009.03.012

54. Shearer MJ, Okano T. Key Pathways and Regulators of Vitamin K Function and Intermediary Metabolism. Annu Rev Nutr (2018) 38(1)38127-51. doi: 10.1146/annurev-nutr-082117-051741

55. Shearer MJ, Newman P. Metabolism and Cell Biology of Vitamin K. Thromb Haemost (2008) 100(4):530-47. doi: 10.1160/TH08-03-0147

56. Thijssen HH, Vervoort LM, Schurgers LJ, Shearer MJ. Menadione is a Metabolite of Oral Vitamin K. Br J Nutr (2006) 95(2):260-6. doi: 10.1079/ BJN20051630

57. Ronden JE, Drittij-Reijnders MJ, Vermeer C, Thijssen HHW. Intestinal Flora is Not an Intermediate in the Phylloquinone-Menaquinone-4 Conversion in the Rat. BBA Gen Subj (1998) 1379(1):69-75. doi: 10.1016/ S0304-4165(97)00089-5

58. Frank DN, St Amand AL, Feldman RA, Boedeker EC, Harpaz N, Pace NR. Molecular-Phylogenetic Characterization of Microbial Community Imbalances in Human Inflammatory Bowel Diseases. Proc Natl Acad Sci USA (2007) 104(34):13780-5. doi: 10.1073/pnas.0706625104

59. Karl JP, Meydani M, Barnett JB, Vanegas SM, Barger K, Fu X, et al. Fecal Concentrations of Bacterially Derived Vitamin K Forms are Associated With Gut Microbiota Composition But Not Plasma or Fecal Cytokine Concentrations in Healthy Adults. Am J Clin Nutr (2017) 106(4):1052-61. doi: 10.3945/ajcn.117.155424

60. Conly JM, Stein K. Quantitative and Qualitative Measurements of K Vitamins in Human Intestinal Contents. Am J Gastroenterol (1992) 87 (3):311-6.

61. Rezaïki L, Lamberet G, Derré A, Gruss A, Gaudu P. Lactococcus Lactis Produces Short-Chain Quinones That Cross-Feed Group B Streptococcus to Activate Respiration Growth. Mol Microbiol (2008) 67(5):947-57. doi: 10.1111/j.1365-2958.2007.06083.x

62. Conly JM, Stein K, Worobetz L, Rutledge-Harding S. The Contribution of Vitamin $\mathrm{K}_{2}$ (Menaquinones) Produced by the Intestinal Microflora to Human Nutritional Requirements for Vitamin K. Am J Gastroenterol (1994) 89(6):915-23. 
63. Karl JP, Fu X, Wang X, Zhao Y, Shen J, Zhang C, et al. Fecal Menaquinone Profiles of Overweight Adults are Associated With Gut Microbiota Composition During a Gut Microbiota-Targeted Dietary Intervention. Am J Clin Nutr (2015) 102(1):84-93. doi: 10.3945/ajcn.115.109496

64. Schurgers LJ, Teunissen KJ, Hamulyak K, Knapen MH, Vik H, Vermeer C. Vitamin K-Containing Dietary Supplements: Comparison of Synthetic Vitamin $K_{1}$ and Natto-Derived Menaquinone-7. Blood (2007) 109 (8):3279-83. doi: 10.1182/blood-2006-08-040709

65. Akiyama Y, Hara K, Matsumoto A, Takahashi S, Tajima T. Comparison of Intestinal Absorption of Vitamin $\mathrm{K}_{2}$ (Menaquinone) Homologues and Their Effects on Blood Coagulation in Rats With Hypoprothrombinaemia. Biochem Pharmacol (1995) 49(12):1801-7. doi: 10.1016/0006-2952(94) 00531-P

66. Sato T, Schurgers LJ, Uenishi K. Comparison of Menaquinone-4 and Menaquinone-7 Bioavailability in Healthy Women. Nutr J (2012) 11 (1):1193. doi: 10.1186/1475-2891-11-93

67. Geleijnse JM, Vermeer C, Grobbee DE, Schurgers LJ, Knapen MH, van der Meer IM, et al. Dietary Intake of Menaquinone is Associated With a Reduced Risk of Coronary Heart Disease: The Rotterdam Study. J Nutr (2004) 134 (11):3100-5. doi: 10.1093/jn/134.11.3100

68. Beulens JWJ, Bots ML, Atsma F, Bartelink MLEL, Prokop M, Geleijnse JM, et al. High Dietary Menaquinone Intake is Associated With Reduced Coronary Calcification. Atherosclerosis (2009) 203(2):489-93. doi: 10.1016/ j.atherosclerosis.2008.07.010

69. Gast GC, de Roos NM, Sluijs I, Bots ML, Beulens JW, Geleijnse JM, et al. A High Menaquinone Intake Reduces the Incidence of Coronary Heart Disease. Nutr Metab Cardiovasc Dis (2009) 19(7):504-10. doi: 10.1016/ j.numecd.2008.10.004

70. Suttie JW. The Importance of Menaquinones in Human Nutrition. Annu Rev Nutr (1995) 15(1):15399-417. doi: 10.1146/annurev.nu.15.070195.002151

71. Iwamoto J, Sato $\mathrm{Y}$, Matsumoto $\mathrm{H}$. Vitamin $\mathrm{K}_{2}$ Improves Femoral Bone Strength Without Altering Bone Mineral Density in Gastrectomized Rats. J Nutr Sci Vitaminol (Tokyo) (2014) 60(2):71-7. doi: 10.3177/jnsv.60.71

72. Urano A, Hotta M, Ohwada R, Araki M. Vitamin K Deficiency Evaluated by Serum Levels of Undercarboxylated Osteocalcin in Patients With Anorexia Nervosa With Bone Loss. Clin Nutr (2015) 34(3):443-8. doi: 10.1016/ j.clnu.2014.04.016

73. Shearer MJ. Vitamin K in Parenteral Nutrition. Gastroenterology (2009) 137 (5 Suppl):S105-118. doi: 10.1053/j.gastro.2009.08.046

74. Glapa A, Waraczewski K, Nowak JK, Paszkowski J, Borejsza-Wysocki M, Krzyzanowska-Jankowska P, et al. Vitamin K Deficiency in Patients After Restorative Proctocolectomy. Inflamm Bowel Dis (2019) 25(3):e17-8. doi: 10.1093/ibd/izy184

75. Nowak JK, Grzybowskachlebowczyk U, Landowski P, Szaflarskapoplawska A, Klincewicz B, Adamczak D, et al. Prevalence and Correlates of Vitamin K Deficiency in Children With Inflammatory Bowel Disease. Sci Rep (2015) 4 (1):4768-8. doi: 10.1038/srep04768

76. Fisher L, Byrnes E, Fisher AA. Prevalence of Vitamin K and Vitamin D Deficiency in Patients With Hepatobiliary and Pancreatic Disorders. Nutr Res (2009) 29(9):676-83. doi: 10.1016/j.nutres.2009.09.001

77. Cozzolino M, Mangano M, Galassi A, Ciceri P, Messa P, Nigwekar S. Vitamin K in Chronic Kidney Disease. Nutrients (2019) 11(1):168. doi: 10.3390/nu11010168

78. Caluwé R, Verbeke F, De Vriese AS. Evaluation of Vitamin K Status and Rationale for Vitamin K Supplementation in Dialysis Patients. Nephrol Dial Transplant (2020) 35(1):23-33. doi: 10.1093/ndt/gfy373

79. Quinn L, Sheh A, Ellis JL, Smith DE, Booth SL, Fu X, et al. Helicobacter Pylori Antibiotic Eradication Coupled With a Chemically Defined Diet in INS-GAS Mice Triggers Dysbiosis and Vitamin K Deficiency Resulting in Gastric Hemorrhage. Gut Microbes (2020) 11(4):820-41. doi: 10.1080/ 19490976.2019.1710092

80. Shearer MJ, Fu X, Booth SL. Vitamin K Nutrition, Metabolism, and Requirements: Current Concepts and Future Research. Adv Nutr (2012) 3 (2):182-95. doi: 10.3945/an.111.001800

81. Ji Y, Li X, Tso P. Intestinal Fatty Acid Absorption. Immunol Endocr Metab Agents Med Chem (2009) 9(1):60-73. doi: 10.2174/187152209788009832

82. Yamanashi Y, Takada T, Kurauchi R, Tanaka Y, Komine T, Suzuki H. Transporters for the Intestinal Absorption of Cholesterol, Vitamin E, and
Vitamin K. J Atheroscler Thromb (2017) 24(4):347-59. doi: 10.5551/ jat.RV16007

83. Schurgers LJ, Vermeer C. Determination of Phylloquinone and Menaquinones in Food - Effect of Food Matrix on Circulating Vitamin K Concentrations. Haemostasis (2000) 30(6):298-307. doi: 10.1159/ 000054147

84. Thijssen HH, Drittij-Reijnders MJ. Vitamin K Status in Human Tissues: Tissue-Specific Accumulation of Phylloquinone and Menaquinone-4. $\mathrm{Br} J$ Nutr (1996) 75(1):121-7. doi: 10.1079/BJN19960115

85. Harshman SG, Fu X, Karl JP, Barger K, Lamon-Fava S, Kuliopulos A, et al. Tissue Concentrations of Vitamin $\mathrm{K}$ and Expression of Key Enzymes of Vitamin K Metabolism Are Influenced by Sex and Diet But Not Housing in C57Bl6 Mice. J Nutr (2016) 146(8):1521-7. doi: 10.3945/jn.116.233130

86. Nakagawa K, Hirota Y, Sawada N, Yuge N, Watanabe M, Uchino Y, et al. Identification of UBIAD1 as a Novel Human Menaquinone-4 Biosynthetic Enzyme. Nature (2010) 468(7320):117-21. doi: 10.1038/nature09464

87. Buitenhuis HC, Soute BA, Vermeer C. Comparison of the Vitamins $K_{1}, K_{2}$ and $\mathrm{K}_{3}$ as Cofactors for the Hepatic Vitamin K-Dependent Carboxylase. Biochim Biophys Acta (1990) 1034(2):170-5. doi: 10.1016/0304-4165(90) 90072-5

88. Harrington DJ, Soper R, Edwards C, Savidge GF, Hodges SJ, Shearer MJ. Determination of the Urinary Aglycone Metabolites of Vitamin K by HPLC With Redox-Mode Electrochemical Detection. J Lipid Res (2005) 46 (5):1053-60. doi: 10.1194/jlr.D400033-JLR200

89. McBurney A, Shearer MJ, Barkhan P. Preparative Isolation and Characterization of the Urinary Aglycones of Vitamin $\mathrm{K}_{1}$ (Phylloquinone in Man. Biochem Med (1980) 24(3):250-67. doi: 10.1016/0006-2944(80) 90020-4

90. Wadelius M, Chen LY, Downes K, Ghori J, Hunt S, Eriksson N, et al. Common VKORC1 and GGCX Polymorphisms Associated With Warfarin Dose. Pharmacogenomics J (2005) 5(4):262-70. doi: 10.1038/sj.tpj.6500313

91. Strople J, Lovell G, Heubi J. Prevalence of Subclinical Vitamin K Deficiency in Cholestatic Liver Disease. J Pediatr Gastroenterol Nutr (2009) 49(1):7884. doi: 10.1097/MPG.0b013e31819a61ff

92. Spohn G, Kleinridders A, Wunderlich FT, Watzka M, Zaucke F, Blumbach $\mathrm{K}$, et al. VKORC1 Deficiency in Mice Causes Early Postnatal Lethality Due to Severe Bleeding. Thromb Haemost (2009) 101(6):1044-50. doi: 10.1160/ TH09-03-0204

93. Tamadon-Nejad S, Ouliass B, Rochford J, Ferland G. Vitamin K Deficiency Induced by Warfarin Is Associated With Cognitive and Behavioral Perturbations, and Alterations in Brain Sphingolipids in Rats. Front Aging Neurosci (2018) 10213. doi: 10.3389/fnagi.2018.00213

94. Krasinski SD, Russell RM, Furie BC, Kruger SF, Jacques PF, Furie B. The Prevalence of Vitamin K Deficiency in Chronic Gastrointestinal Disorders. Am J Clin Nutr (1985) 3):3. doi: 10.1093/ajcn/41.3.639

95. Hutton ARJ, Quinn HL, McCague PJ, Jarrahian C, Rein-Weston A, Coffey PS, et al. Transdermal Delivery of Vitamin K Using Dissolving Microneedles for the Prevention of Vitamin K Deficiency Bleeding. Int J Pharm (2018) 541 (1-2):56-63. doi: 10.1016/j.ijpharm.2018.02.031

96. Fong-Ngern K, Ausakunpipat N, Singhto N, Sueksakit K, Thongboonkerd V. Prolonged $\mathrm{K}(+)$ Deficiency Increases Intracellular ATP, Cell Cycle Arrest and Cell Death in Renal Tubular Cells. Metabolism (2017) 74:7447-61. doi: 10.1016/j.metabol.2016.12.014

97. Rai RK, Luo J, Tulchinsky TH. Vitamin K Supplementation to Prevent Hemorrhagic Morbidity and Mortality of Newborns in India and China. World J Pediatr (2017) 13(1):15-9. doi: 10.1007/s12519-016-0062-6

98. Kuwabara A, Tanaka K, Tsugawa N, Nakase H, Tsuji H, Shide K, et al. High Prevalence of Vitamin K and D Deficiency and Decreased BMD in Inflammatory Bowel Disease. Osteoporos Int (2009) 20(6):935-42. doi: 10.1007/s00198-008-0764-2

99. Nakajima S, Iijima H, Egawa S, Shinzaki S, Kondo J, Inoue T, et al. Association of Vitamin K Deficiency With Bone Metabolism and Clinical Disease Activity in Inflammatory Bowel Disease. Nutrition (2011) 27 (10):1023-8. doi: 10.1016/j.nut.2010.10.021

100. Nowak JK, Grzybowska-Chlebowczyk U, Landowski P, SzaflarskaPoplawska A, Klincewicz B, Adamczak D, et al. Prevalence and Correlates of Vitamin K Deficiency in Children With Inflammatory Bowel Disease. Sci Rep (2014) 44768:4768. doi: 10.1038/srep04768 
101. Krzyżanowska P, Książyk J, Kocielińska-Kłos M, Banaś E, Kaleta M, Popińska K, et al. Vitamin K Status in Patients With Short Bowel Syndrome. Clin Nutr (2012) 31(6):1015-7. doi: 10.1016/j.clnu.2012.04.014

102. Fabisiak N, Fabisiak A, Watala C, Fichna J. Fat-Soluble Vitamin Deficiencies and Inflammatory Bowel Disease: Systematic Review and Meta-Analysis. J Clin Gastroenterol (2017) 51(10):878-89. doi: 10.1097/MCG.0000000000000911

103. Santoru ML, Piras C, Murgia A, Palmas V, Camboni T, Liggi S, et al. Cross Sectional Evaluation of the Gut-Microbiome Metabolome Axis in an Italian Cohort of IBD Patients. Sci Rep (2017) 7(1):9523. doi: 10.1038/s41598-01710034-5

104. Schoon EJ, Müller MC, Vermeer C, Schurgers LJ, Brummer RJ, Stockbrügger RW. Low Serum and Bone Vitamin K Status in Patients With Longstanding Crohn's Disease: Another Pathogenetic Factor of Osteoporosis in Crohn's Disease? Gut (2001) 48(4):473-7. doi: 10.1136/gut.48.4.473

105. Ratajczak AE, Rychter AM, Zawada A, Dobrowolska A, Krela-Kaźmierczak I. Nutrients in the Prevention of Osteoporosis in Patients With Inflammatory Bowel Diseases. Nutrients (2020) 12(6):1702. doi: 10.3390/ nu12061702

106. Vestergaard P. Bone Loss Associated With Gastrointestinal Disease: Prevalence and Pathogenesis. Eur J Gastroenterol Hepatol (2003) 15 (8):851-6. doi: 10.1097/00042737-200308000-00003

107. Vestergaard P. Prevalence and Pathogenesis of Osteoporosis in Patients With Inflammatory Bowel Disease. Minerva Med (2004) 95(6):469-80. doi: 10.1136/gut.28.4.410

108. Shea MK, Booth SL, Massaro JM, Jacques PF, Dagostino RB, Dawsonhughes B, et al. Vitamin K and Vitamin D Status: Associations With Inflammatory Markers in the Framingham Offspring Study. Am J Epidemiol (2007) 167 (3):313-20. doi: 10.1093/aje/kwm306

109. Ravishankar B, Dound YA, Mehta DS, Ashok BK, de Souza A, Pan MH, et al. Safety Assessment of Menaquinone-7 for Use in Human Nutrition. J Food Drug Anal (2015) 23(1):99-108. doi: 10.1016/j.jfda.2014.03.001

110. Marles RJ, Roe AL, Oketch-Rabah HA. US Pharmacopeial Convention Safety Evaluation of Menaquinone-7, a Form of Vitamin K. Nutr Rev (2017) 75 (7):553-78. doi: 10.1093/nutrit/nux022

111. Delaney SJ, Dzanis DA. Safety of Vitamin K, and its Use in Pet Foods. J Am Vet Med Assoc (2018) 252(5):537-42. doi: 10.2460/javma.252.5.537

112. Quick AJ, Collentine GEJr., Hussey CV. Vitamin K Requirements of the Growing Pup. J Nutr (1962) 77(1):28-32. doi: 10.1093/jn/77.1.28

113. NRC Subcommittee on Vitamin Tolerance. Vitamin K. In: Vitamin Tolerance of Animals. washington, DC: The National Academies Press (1987). p. 31-5.

114. Ohsaki Y, Shirakawa H, Hiwatashi K, Furukawa Y, Mizutani T, Komai M. Vitamin K Suppresses Lipopolysaccharide-Induced Inflammation in the Rat. Biosci Biotechnol Biochem (2006) 70(4):926-32. doi: 10.1271/bbb.70.926

115. Ohsaki Y, Shirakawa H, Miura A, Giriwono PE, Sato S, Ohashi A, et al. Vitamin K Suppresses the Lipopolysaccharide-Induced Expression of Inflammatory Cytokines in Cultured Macrophage-Like Cells via the Inhibition of the Activation of Nuclear Factor $\mathrm{kb}$ Through the Repression of IKK $\alpha / \beta$ Phosphorylation. J Nutr Biochem (2010) 21(11):1120-6. doi: 10.1016/j.jnutbio.2009.09.011

116. Zheng X, Hou Y, He H, Chen Y, Zhou R, Wang X, et al. Synthetic Vitamin K Analogs Inhibit Inflammation by Targeting the NLRP3 Inflammasome. Cell Mol Immunol (2021) 18(10):2422-30. doi: 10.1038/s41423-020-00545-Z

117. Reddi K, Henderson B, Meghji S, Wilson M, Poole S, Hopper C, et al. Interleukin 6 Production by Lipopolysaccharide-Stimulated Human Fibroblasts is Potently Inhibited by Naphthoquinone (Vitamin K) Compounds. Cytokine (1995) 7(3):287-90. doi: 10.1006/cyto.1995.0034

118. D'Odorico A, Sturniolo GC, Bilton RF, Morris AI, Gilmore IT, Naccarato R. Quinone-Induced DNA Single Strand Breaks in a Human Colon Carcinoma Cell Line. Carcinogenesis (1997) 18(1):43-6. doi: 10.1093/carcin/18.1.43

119. Sogabe N, Maruyama R, Hosori T, Goseki-Sone M. Enhancement Effects of Vitamin $\mathrm{K}_{1}$ (Phylloquinone) or Vitamin $\mathrm{K}_{2}$ (Menaquinone-4) on Intestinal Alkaline Phosphatase Activity in Rats. J Nutr Sci Vitaminol (Tokyo) (2007) 53(3):219-24. doi: 10.3177/jnsv.53.219

120. Haraikawa M, Sogabe N, Tanabe R, Hosoi T, Goseki-Sone M. Vitamin $K_{1}$ (Phylloquinone) or Vitamin $\mathrm{K}_{2}$ (Menaquinone-4) Induces Intestinal Alkaline Phosphatase Gene Expression. J Nutr Sci Vitaminol (Tokyo) (2011) 57(4):274-9. doi: 10.3177/jnsv.57.274
121. Mathers JC, Fernandez F, Hill MJ, McCarthy PT, Shearer MJ, Oxley A. Dietary Modification of Potential Vitamin K Supply From Enteric Bacterial Menaquinones in Rats. Br J Nutr (1990) 63(3):639-52. doi: 10.1079/ BJN19900150

122. Orlando A, Linsalata M, Russo F. Antiproliferative Effects on Colon Adenocarcinoma Cells Induced by Co-Administration of Vitamin $\mathrm{K}_{1}$ and Lactobacillus Rhamnosus GG. Int J Oncol (2016) 48(6):2629-38. doi: 10.3892/ijo.2016.3463

123. Allegretti J, Eysenbach LM, El-Nachef N, Fischer M, Kelly C, Kassam Z. The Current Landscape and Lessons From Fecal Microbiota Transplantation for Inflammatory Bowel Disease: Past, Present, and Future. Inflamm Bowel Dis (2017) 23(10):1710-7. doi: 10.1097/MIB.0000000000001247

124. Franzosa EA, Sirota-Madi A, Avila-Pacheco J, Fornelos N, Haiser HJ, Reinker S, et al. Gut Microbiome Structure and Metabolic Activity in Inflammatory Bowel Disease. Nat Microbiol (2019) 4(2):293-305. doi: 10.1038/s41564-018-0306-4

125. Koh A, De Vadder F, Kovatcheva-Datchary P, Bäckhed F. From Dietary Fiber to Host Physiology: Short-Chain Fatty Acids as Key Bacterial Metabolites. Cell (2016) 165(6):1332-45. doi: 10.1016/j.cell.2016.05.041

126. Walther B, Chollet M. Menaquinones, Bacteria, and Foods: Vitamin $\mathrm{K}_{2}$ in the Diet. London: InTech (2017). doi: 10.5772/63712

127. Giuliano V, Bassotti G, Mourvaki E, Castellani D, Filippucci E, Sabatino G, et al. Small Intestinal Bacterial Overgrowth and Warfarin Dose Requirement Variability. Thromb Res (2010) 126(1):12-7. doi: 10.1016/ j.thromres.2009.11.032

128. Ponziani FR, Pompili M, Di Stasio E, Zocco MA, Gasbarrini A, Flore R. Subclinical Atherosclerosis is Linked to Small Intestinal Bacterial Overgrowth via Vitamin $\mathrm{K}_{2}$-Dependent Mechanisms. World J Gastroenterol (2017) 23(7):1241-9. doi: 10.3748/wjg.v23.i7.1241

129. Wagatsuma K, Yamada S, Ao M, Matsuura M, Tsuji H, Iida T, et al. Diversity of Gut Microbiota Affecting Serum Level of Undercarboxylated Osteocalcin in Patients With Crohn's Disease. Nutrients (2019) 11(7):1541. doi: 10.3390/ nu11071541

130. Ellis JL, Karl JP, Oliverio AM, Fu X, Soares JW, Wolfe BE, et al. Dietary Vitamin K is Remodeled by Gut Microbiota and Influences Community Composition. Gut Microbes (2021) 13(1):1-16. doi: 10.1080/19490976.2021.1887721

131. Quarta G, Kim S, Cho I, Blaser M. Mo1817 Warfarin Induces Intestinal Dysbiosis Involving Vitamin K-Expressing Bacteria. Gastroenterology (2015) 148(4, Supplement 1):S-718. doi: 10.1016/S0016-5085(15)32447-1

132. Boris S, Barbes C. Role Played by Lactobacilli in Controlling the Population of Vaginal Pathogens. Microbes Infect (2000) 2(5):543-6. doi: 10.1016/ S1286-4579(00)00313-0

133. Rio-Rodriguez RED, Inglis V, Millar SD. Survival of Escherichia Coli in the Intestine of Fish. Aquac Res (1997) 28(4):257-64. doi: 10.1111/j.13652109.1997.tb01041.x

134. Merino S, Rubires X, Knochel S, Tomas JM. Emerging Pathogens: Aeromonas Spp. Int J Food Microbiol (1995) 28(2):157-68. doi: 10.1016/ 0168-1605(95)00054-2

135. Hojo K, Nagaoka S, Murata S, Taketomo N, Ohshima T, Maeda N. Reduction of Vitamin K Concentration by Salivary Bifidobacterium Strains and Their Possible Nutritional Competition With Porphyromonas Gingivalis. J Appl Microbiol (2007) 103(5):1969-74. doi: 10.1111/j.13652672.2007.03436.x

136. Eslami M, Yousefi B, Kokhaei P, Hemati M, Nejad ZR, Arabkari V, et al. Importance of Probiotics in the Prevention and Treatment of Colorectal Cancer. J Cell Physiol (2019) 234(10):17127-43. doi: 10.1002/jcp.28473

137. Hale MB, Blankenship RE, Fuller RC. Menaquinone is the Sole Quinone in the Facultatively Aerobic Green Photosynthetic Bacterium Chloroflexus Aurantiacus. Biochim Biophys Acta (BBA) - Bioenerg (1983) 723(3):37682. doi: 10.1016/0005-2728(83)90044-0

138. Bui TP, Ritari J, Boeren S, de Waard P, Plugge CM, de Vos WM. Production of Butyrate From Lysine and the Amadori Product Fructoselysine by a Human Gut Commensal. Nat Commun (2015) 6:610062. doi: 10.1038/ ncomms 10062

139. Plöger S, Stumpff F, Penner GB, Schulzke JD, Gäbel G, Martens H, et al. Microbial Butyrate and its Role for Barrier Function in the Gastrointestinal Tract. Ann N Y Acad Sci (2012) 1258(1):125852-59. doi: 10.1111/j.17496632.2012.06553.x 
140. Schulthess J, Pandey S, Capitani M, Rue-Albrecht KC, Arnold I, Franchini F, et al. The Short Chain Fatty Acid Butyrate Imprints an Antimicrobial Program in Macrophages. Immunity (2019) 50(2):432-445.e437. doi: 10.1016/j.immuni.2018.12.018

141. Chen J, Vitetta L. The Role of Butyrate in Attenuating Pathobiont-Induced Hyperinflammation. Immune Netw (2020) 20(2):e15. doi: 10.4110/ in.2020.20.e15

142. Arpaia N, Campbell C, Fan X, Dikiy S, van der Veeken J, deRoos P, et al. Metabolites Produced by Commensal Bacteria Promote Peripheral Regulatory T-Cell Generation. Nature (2013) 504(7480):451-5. doi: 10.1038/nature12726

143. Wu W, Sun M, Chen F, Cao AT, Liu H, Zhao Y, et al. Microbiota Metabolite Short-Chain Fatty Acid Acetate Promotes Intestinal IgA Response to Microbiota Which is Mediated by GPR43. Mucosal Immunol (2017) 10 (4):946-56. doi: 10.1038/mi.2016.114

144. Laserna-Mendieta EJ, Clooney AG, Carretero-Gomez JF, Moran C, Sheehan D, Nolan JA, et al. Determinants of Reduced Genetic Capacity for Butyrate Synthesis by the Gut Microbiome in Crohn's Disease and Ulcerative Colitis. J Crohns Colitis (2018) 12(2):204-16. doi: 10.1093/ecco-jcc/jjx137

145. Machiels K, Joossens M, Sabino J, De Preter V, Arijs I, Eeckhaut V, et al. A Decrease of the Butyrate-Producing Species Roseburia Hominis and Faecalibacterium Prausnitzii Defines Dysbiosis in Patients With Ulcerative Colitis. Gut (2014) 63(8):1275-83. doi: 10.1136/gutjnl-2013-304833

146. Rezaie A, Parker RD, Abdollahi M. Oxidative Stress and Pathogenesis of Inflammatory Bowel Disease: An Epiphenomenon or the Cause? Dig Dis Sci (2007) 52(9):2015-21. doi: 10.1007/s10620-006-9622-2

147. Sies H. Oxidative Stress: A Concept in Redox Biology and Medicine. Redox Biol (2015) 4:4180-183. doi: 10.1016/j.redox.2015.01.002

148. Castiglione GM, Xu Z, Zhou L, Duh EJ. Adaptation of the Master Antioxidant Response Connects Metabolism, Lifespan and Feather Development Pathways in Birds. Nat Commun (2020) 11(1):2476. doi: 10.1038/s41467-020-16129-4

149. Pereira C, Grácio D, Teixeira JP, Magro F. Oxidative Stress and DNA Damage: Implications in Inflammatory Bowel Disease. Inflamm Bowel Dis (2015) 21(10):2403-17. doi: 10.1097/MIB.0000000000000506

150. Piechota-Polanczyk A, Fichna J. Review Article: The Role of Oxidative Stress in Pathogenesis and Treatment of Inflammatory Bowel Diseases. N-S Arch Pharmacol (2014) 387(7):605-20. doi: 10.1007/s00210-014-0985-1

151. Fu J, Xu W, Mai K, Zhang W, Feng X, Liufu Z. Effects of Dietary Menadione on the Activity of Antioxidant Enzymes in Abalone, Haliotis Discus Hannai Ino. Chin J Oceanol Limnol (2012) 30(1):118-23. doi: 10.1007/s00343-012-1014-1

152. Stephensen E, Sturve J, Forlin L. Effects of Redox Cycling Compounds on Glutathione Content and Activity of Glutathione-Related Enzymes in Rainbow Trout Liver. Comp Biochem Physiol C Toxicol Pharmacol (2002) 133(3):435-42. doi: 10.1016/S1532-0456(02)00129-1

153. Mukai K, Morimoto H, Kikuchi S, Nagaoka S. Kinetic Study of Free-RadicalScavenging Action of Biological Hydroquinones (Reduced Forms of Ubiquinone, Vitamin K and Tocopherol Quinone) in Solution. Biochim Biophys Acta (1993) 1157(3):313-7. doi: 10.1016/0304-4165(93)90115-O

154. Li J, Wang H, Rosenberg PA. Vitamin K Prevents Oxidative Cell Death by Inhibiting Activation of 12-Lipoxygenase in Developing Oligodendrocytes. $J$ Neurosci Res (2009) 87(9):1997-2005. doi: 10.1002/jnr.22029

155. Hadipour E, Tayarani-Najaran Z, Fereidoni M. Vitamin $K_{2}$ Protects PC12 Cells Against Abeta (1-42) and H2O2-Induced Apoptosis via P38 MAP Kinase Pathway. Nutr Neurosci (2018) 23(5):343-52. doi: 10.1080/ 1028415X.2018.15044281-10

156. Rao R. Oxidative Stress-Induced Disruption of Epithelial and Endothelial Tight Junctions. Front Biosci (2008) 13: 137210-26. doi: 10.2741/3223

157. HALT-IT Trial Collaborators, Effects of a High-Dose 24-H Infusion of Tranexamic Acid on Death and Thromboembolic Events in Patients With Acute Gastrointestinal Bleeding (HALT-IT): An International Randomised, Double-Blind, Placebo-Controlled Trial. Lancet (2020) 395(10241):1927-36. doi: $10.1016 / \mathrm{S} 0140-6736(20) 30848-5$

158. Demir N, Peker E, Demirören K, Kaba S, Tuncer O. Massive Gastrointestinal Bleeding Due to Vitamin K Deficiency in a Newborn. East J Med (2015) 20 (4):238-40. doi: 10.1155/2015/274639

159. Sherwood MW, Nessel CC, Hellkamp AS, Mahaffey KW, Piccini JP, Suh EY, et al. Gastrointestinal Bleeding in Patients With Atrial Fibrillation Treated
With Rivaroxaban or Warfarin: ROCKET AF Trial. J Am Coll Cardiol (2015) 66(21):2271-81. doi: 10.1016/j.jacc.2015.09.024

160. Cangemi DJ, Krill T, Weideman R, Cipher DJ, Spechler SJ, Feagins LA. A Comparison of the Rate of Gastrointestinal Bleeding in Patients Taking NonVitamin K Antagonist Oral Anticoagulants or Warfarin. Am J Gastroenterol (2017) 112(5):734-9. doi: 10.1038/ajg.2017.39

161. Hearnshaw SA, Logan RF, Lowe D, Travis SP, Murphy MF, Palmer KR. Acute Upper Gastrointestinal Bleeding in the UK: Patient Characteristics, Diagnoses and Outcomes in the 2007 UK Audit. Gut (2011) 60(10):1327-35. doi: 10.1136/gut.2010.228437

162. Oakland K, Guy R, Uberoi R, Hogg R, Mortensen N, Murphy MF, et al. Acute Lower GI Bleeding in the UK: Patient Characteristics, Interventions and Outcomes in the First Nationwide Audit. Gut (2018) 67(4):654-62. doi: 10.1136/gutjnl-2016-313428

163. Pineo GF, Gallus AS, Hirsh J. Unexpected Vitamin K Deficiency in Hospitalized Patients. Can Med Assoc J (1973) 109(9):880-3.

164. Fountoulaki E, Alexis MN, Nengas I, Venou B. Effect of Diet Composition on Nutrient Digestibility and Digestive Enzyme Levels of Gilthead Sea Bream (Sparus Aurata L.). Aquac Res (2005) 36(13):1243-51. doi: 10.1111/j.13652109.2005.01232.x

165. Goldberg RF, Austen WGJr., Zhang X, Munene G, Mostafa G, Biswas S, et al. Intestinal Alkaline Phosphatase is a Gut Mucosal Defense Factor Maintained by Enteral Nutrition. Proc Natl Acad Sci USA (2008) 105(9):3551-6. doi: 10.1073/pnas.0712140105

166. Lalles JP. Intestinal Alkaline Phosphatase: Multiple Biological Roles in Maintenance of Intestinal Homeostasis and Modulation by Diet. Nutr Rev (2010) 68(6):323-32. doi: 10.1111/j.1753-4887.2010.00292.x

167. Kim SB, Calmet FH, Garrido J, Garcia-Buitrago MT, Moshiree B. SucraseIsomaltase Deficiency as a Potential Masquerader in Irritable Bowel Syndrome. Dig Dis Sci (2020) 65(2):534-40. doi: 10.1007/s10620-01905780-7

168. Tabb MM, Sun A, Zhou C, Grun F, Errandi J, Romero K, et al. Vitamin $\mathrm{K}_{2}$ Regulation of Bone Homeostasis is Mediated by the Steroid and Xenobiotic Receptor SXR. J Biol Chem (2003) 278(45):43919-27. doi: 10.1074/ jbc.M303136200

169. Suhara $\mathrm{Y}$, Watanabe $\mathrm{M}$, Nakagawa K, Wada A, Ito $\mathrm{Y}$, Takeda K, et al. Synthesis of Novel Vitamin $K_{2}$ Analogues With Modification at the $\omega$ Terminal Position and Their Biological Evaluation as Potent Steroid and Xenobiotic Receptor (SXR) Agonists. J Med Chem (2011) 54(12):4269-73. doi: $10.1021 / \mathrm{jm} 200025 \mathrm{f}$

170. Sultana H, Watanabe K, Rana MM, Takashima R, Ohashi A, Komai M, et al. Effects of Vitamin $\mathrm{K}_{2}$ on the Expression of Genes Involved in Bile Acid Synthesis and Glucose Homeostasis in Mice With Humanized PXR. Nutrients (2018) 10(8):982. doi: 10.3390/nu10080982

171. Mani S, Dou W, Redinbo MR. PXR Antagonists and Implication in Drug Metabolism. Drug Metab Rev (2013) 45(1):60-72. doi: 10.3109/ 03602532.2012.746363

172. Dou W, Mukherjee S, Li H, Venkatesh M, Wang H, Kortagere S, et al. Alleviation of Gut Inflammation by Cdx2/Pxr Pathway in a Mouse Model of Chemical Colitis. PloS One (2012) 7(7):e36075. doi: 10.1371/journal.pone.0036075

173. Dou W, Zhang J, Zhang E, Sun A, Ding L, Chou G, et al. Chrysin Ameliorates Chemically Induced Colitis in the Mouse Through Modulation of a PXR/NFКB Signaling Pathway. J Pharmacol Exp Ther (2013) 345(3):473-82. doi: 10.1124/jpet.112.201863

174. Wu S, Liao AP, Xia Y, Li YC, Li JD, Sartor RB, et al. Vitamin D Receptor Negatively Regulates Bacterial-Stimulated NF-kappaB Activity in Intestine. Am J Pathol (2010) 177(2):686-97. doi: 10.2353/ajpath.2010.090998

175. Liu W, Chen Y, Golan MA, Annunziata ML, Du J, Dougherty U, et al. Intestinal Epithelial Vitamin D Receptor Signaling Inhibits Experimental Colitis. J Clin Invest (2013) 123(9):3983-96. doi: $10.1172 /$ JCI65842

176. Chen Y, Du J, Zhang Z, Liu T, Shi Y, Ge X, et al. MicroRNA-346 Mediates Tumor Necrosis Factor $\alpha$-Induced Downregulation of Gut Epithelial Vitamin D Receptor in Inflammatory Bowel Diseases. Inflamm Bowel Dis (2014) 20(11):1910-8. doi: 10.1097/MIB.0000000000000158

177. Lu R, Zhang YG, Xia Y, Sun J. Imbalance of Autophagy and Apoptosis in Intestinal Epithelium Lacking the Vitamin D Receptor. FASEB J (2019) 33 (11):11845-56. doi: 10.1096/ff.201900727R 
178. Jin D, Wu S, Zhang YG, Lu R, Xia Y, Dong H, et al. Lack of Vitamin D Receptor Causes Dysbiosis and Changes the Functions of the Murine Intestinal Microbiome. Clin Ther (2015) 37(5):996-1009.e1007. doi: 10.1016/j.clinthera.2015.04.004

179. Larriba MJ, Ordóñez-Morán P, Chicote I, Martín-Fernández G, Puig I, Muñoz A, et al. Vitamin D Receptor Deficiency Enhances Wnt/ $\beta$-Catenin Signaling and Tumor Burden in Colon Cancer. PloS One (2011) 6(8):e23524. doi: 10.1371/journal.pone.0023524

180. Barbáchano A, Fernández-Barral A, Ferrer-Mayorga G, Costales-Carrera A, Larriba MJ, Muñoz A. The Endocrine Vitamin D System in the Gut. Mol Cell Endocrinol (2017) 453:79-87. doi: 10.1016/j.mce.2016.11.028

181. Bakke D, Sun J. Ancient Nuclear Receptor VDR With New Functions: Microbiome and Inflammation. Inflamm Bowel Dis (2018) 24(6):1149-54. doi: 10.1093/ibd/izy092

182. Sergeev IN, Spirichev VB. [The Role of Vitamin K in the Interaction of 1,25Dihydroxyvitamin D3 Receptors With DNA]. Biull Eksp Biol Med (1988) 106 (12):695-8.

183. Sergeev IN, Norman AW. Vitamin K-Dependent Gamma-Carboxylation of the 1,25-Dihydroxyvitamin D3 Receptor. Biochem Biophys Res Commun (1992) 189(3):1543-7. doi: 10.1016/0006-291X(92)90251-F

184. Sun X, Yang Q, Rogers CJ, Du M, Zhu MJ. AMPK Improves Gut Epithelial Differentiation and Barrier Function via Regulating Cdx2 Expression. Cell Death Differ (2017) 24(5):819-31. doi: 10.1038/cdd.2017.14

185. Olivier S, Leclerc J, Grenier A, Foretz M, Tamburini J, Viollet B. AMPK Activation Promotes Tight Junction Assembly in Intestinal Epithelial Caco-2 Cells. Int J Mol Sci (2019) 20(20):5171. doi: 10.3390/ijms20205171

186. Li W, Wang QL, Liu X, Dong SH, Li HX, Li CY, et al. Combined Use of Vitamin D3 and Metformin Exhibits Synergistic Chemopreventive Effects on Colorectal Neoplasia in Rats and Mice. Cancer Prev Res (Phila) (2015) 8 (2):139-48. doi: 10.1158/1940-6207.CAPR-14-0128

187. Liu C, Feng X, Li Q, Wang Y, Li Q, Hua M. Adiponectin, TNF-Alpha and Inflammatory Cytokines and Risk of Type 2 Diabetes: A Systematic Review and Meta-Analysis. Cytokine (2016) 86:100-9. doi: 10.1016/j.cyto.2016.06.028

188. Okamoto Y, Kihara S, Funahashi T, Matsuzawa Y, Libby P. Adiponectin: A Key Adipocytokine in Metabolic Syndrome. Clin Sci (Lond) (2006) 110 (3):267-78. doi: 10.1042/CS20050182

189. Fujisawa T, Endo H, Tomimoto A, Sugiyama M, Takahashi H, Saito S, et al. Adiponectin Suppresses Colorectal Carcinogenesis Under the High-Fat Diet Condition. Gut (2008) 57(11):1531-8. doi: 10.1136/gut.2008.159293

190. Shogan BD, Smith DP, Christley S, Gilbert JA, Zaborina O, Alverdy JC. Intestinal Anastomotic Injury Alters Spatially Defined Microbiome Composition and Function. Microbiome (2014), 235-35. doi: 10.1186/2049-2618-2-35

191. Berkner KL, Runge KW. The Physiology of Vitamin K Nutriture and Vitamin K-Dependent Protein Function in Atherosclerosis. J Thromb Haemost (2004) 2(12):2118-32. doi: 10.1111/j.1538-7836.2004.00968.x

192. Bouchard BA, Furie BC. Vitamin K-Dependent Biosynthesis of GammaCarboxyglutamic Acid. Blood (1999) 93(6):1798-808. doi: 10.1182/ blood.V93.6.1798.406k22_1798_1808

193. Hill HS, Grams J, Walton RG, Liu J, Moellering DR, Garvey WT. Carboxylated and Uncarboxylated Forms of Osteocalcin Directly Modulate the Glucose Transport System and Inflammation in Adipocytes. Horm Metab Res (2014) 46(05):341-7. doi: 10.1055/s-0034-1368709

194. Berkner KL. The Vitamin K-Dependent Carboxylase. Annu Rev Nutr (2005) 25(1):127-49. doi: 10.1146/annurev.nutr.25.050304.092713

195. Lin XH, Wang HC, Wei DD, Wang B, Quan-Xing GE, Bai CY, et al. Study of the Change and Role of Protein C System in Ulcerate Colitis. Acta Physiol Sin (2015) 67(2):214-24. doi: 10.13294/j.aps.2015.0026

196. Aadland E, Odegaard OR, Røseth A, Try K. Free Protein S Deficiency in Patients With Crohn's Disease. Scand J Gastroenterol (1994) 29(4):333-5. doi: 10.3109/00365529409094844

197. Akitake-Kawano R, Seno H, Nakatsuji M, Kimura Y, Nakanishi Y, Yoshioka $\mathrm{T}$, et al. Inhibitory Role of Gas6 in Intestinal Tumorigenesis. Carcinogenesis (2013) 34(7):1567-74. doi: 10.1093/carcin/bgt069

198. Feng Y, Liao Y, Huang W, Lai X, Luo J, Du C, et al. Mesenchymal Stromal CellsDerived Matrix Gla Protein Contribute to the Alleviation of Experimental Colitis. Cell Death Dis (2018) 9(6):1-14. doi: 10.1038/s41419-018-0734-3

199. Wu X, Dai J, Xu X, Li F, Li L, Lu Y, et al. Prothrombin Arg541Trp Mutation Leads to Defective PC (Protein C) Pathway Activation and Constitutes a
Novel Genetic Risk Factor for Venous Thrombosis. Arterioscler Thromb Vasc Biol (2020) 40(2):483-94. doi: 10.1161/ATVBAHA.119.313373

200. Tsiolakidou G, Koutroubakis IE. Thrombosis and Inflammatory Bowel Disease-the Role of Genetic Risk Factors. World J Gastroenterol (2008) 14 (28):4440-4. doi: 10.3748/wjg.14.4440

201. Hayat M, Ariens RA, Moayyedi P, Grant PJ, O’Mahony S. Coagulation Factor XIII and Markers of Thrombin Generation and Fibrinolysis in Patients With Inflammatory Bowel Disease. Eur J Gastroenterol Hepatol (2002) 14(3):249-56. doi: 10.1097/00042737-200203000-00008

202. Papi C, Ciaco A, Acierno G, Di Battista G, Talamanca LF, Lo Russo F, et al. Severe Ulcerative Colitis, Dural Sinus Thrombosis, and the Lupus Anticoagulant. Am J Gastroenterol (1995) 90(9):1514-7.

203. Danese S, Vetrano S, Zhang L, Poplis VA, Castellino FJ. The Protein C Pathway in Tissue Inflammation and Injury: Pathogenic Role and Therapeutic Implications. Blood (2010) 115(6):1121-30. doi: 10.1182/ blood-2009-09-201616

204. Owczarek D, Cibor D, Salapa K, Ciesla A, Glowacki MK, Pocztar H, et al. Anti-Inflammatory and Anticoagulant Properties of the Protein C System in Inflammatory Bowel Disease. Pol Arch Med Wewn (2012) 122(5):209-16. doi: 10.20452/pamw.1261

205. Lin X, Wang H, Li Y, Yang J, Yang R, Wei D, et al. Functional Characterization of CXCR4 in Mediating the Expression of Protein C System in Experimental Ulcerative Colitis. Am J Transl Res (2017) 9(11):4821-35.

206. Lust M, Vulcano M, Danese S. The Protein C Pathway in Inflammatory Bowel Disease: The Missing Link Between Inflammation and Coagulation. Trends Mol Med (2008) 14(6):237-44. doi: 10.1016/j.molmed.2008.03.005

207. Scaldaferri F, Sans M, Vetrano S, Graziani C, De Cristofaro R, Gerlitz B, et al. Crucial Role of the Protein C Pathway in Governing Microvascular Inflammation in Inflammatory Bowel Disease. J Clin Invest (2007) 117 (7):1951-60. doi: 10.1172/JCI31027

208. D’Alessio S, Genua M, Vetrano S. The Protein C Pathway in Intestinal Barrier Function: Challenging the Hemostasis Paradigm. Ann N Y Acad Sci (2012) 1258(1):78-85. doi: 10.1111/j.1749-6632.2012.06557.x

209. Iijima H, Shinzaki S, Takehara T. The Importance of Vitamins D and K for the Bone Health and Immune Function in Inflammatory Bowel Disease. Curr Opin Clin Nutr Metab Care (2012) 15(6):635-40. doi: 10.1097/MCO.0b013e328357f623

210. Schwarz HP, Muntean W, Watzke H, Richter B, Griffin JH. Low Total Protein S Antigen But High Protein S Activity Due to Decreased C4bBinding Protein in Neonates. Blood (1988) 71(3):562-5. doi: 10.1182/ blood.V71.3.562.bloodjournal713562

211. van der Meer JH, van der Poll T, van 't Veer C. TAM Receptors, Gas6, and Protein S: Roles in Inflammation and Hemostasis. Blood (2014) 123 (16):2460-9. doi: 10.1182/blood-2013-09-528752

212. Wakefield AJ, Sawyerr AM, Dhillon AP, Pittilo RM, Rowles PM, Lewis AA, et al. Pathogenesis of Crohn's Disease: Multifocal Gastrointestinal Infarction. Lancet (1989) 2(8671):1057-62. doi: 10.1016/S0140-6736(89)91078-7

213. Saibeni S, Vecchi M, Valsecchi C, Faioni EM, Razzari C, Franchis RD. Reduced Free Protein S Levels in Patients With Inflammatory Bowel Disease. Dig Dis Sci (2001) 46(3):637-43. doi: 10.1023/A:1005675921664

214. Wyshock E, Caldwell M, Crowley JP. Deep Venous Thrombosis, Inflammatory Bowel Disease, and Protein S Deficiency. Am J Clin Pathol (1988) 90(5):633-5. doi: 10.1093/ajcp/90.5.633

215. Yanagita M, Ishimoto Y, Arai H, Nagai K, Ito T, Nakano T, et al. Essential Role of Gas6 for Glomerular Injury in Nephrotoxic Nephritis. J Clin Invest (2002) 110(2):239-46. doi: 10.1172/JCI0214861

216. Rothlin CV, Ghosh S, Zuniga EI, Oldstone MB, Lemke G. TAM Receptors are Pleiotropic Inhibitors of the Innate Immune Response. Cell (2007) 131 (6):1124-36. doi: 10.1016/j.cell.2007.10.034

217. Sawabu T, Seno H, Kawashima T, Fukuda A, Uenoyama Y, Kawada M, et al. Growth Arrest-Specific Gene 6 and Axl Signaling Enhances Gastric Cancer Cell Survival via Akt Pathway. Mol Carcinog (2007) 46(2):155-64. doi: $10.1002 / \mathrm{mc} .20211$

218. Munroe PB, Olgunturk RO, Fryns JP, Van Maldergem L, Ziereisen F, Yuksel B, et al. Mutations in the Gene Encoding the Human Matrix Gla Protein Cause Keutel Syndrome. Nat Genet (1999) 21(1):142-4. doi: 10.1038/5102

219. Schurgers LJ, Cranenburg EC, Vermeer C. Matrix Gla-Protein: The Calcification Inhibitor in Need of Vitamin K. Thromb Haemost (2008) 100 (4):593-603. doi: 10.1160/TH08-02-0087 
220. Roumeliotis S, Dounousi E, Eleftheriadis T, Liakopoulos V. Association of the Inactive Circulating Matrix Gla Protein With Vitamin K Intake, Calcification, Mortality, and Cardiovascular Disease: A Review. Int J Mol Sci (2019) 20(3):628. doi: 10.3390/ijms20030628

221. Brnic D, Martinovic D, Zivkovic PM, Tokic D, Vilovic M, Rusic D, et al. Inactive Matrix Gla Protein is Elevated in Patients With Inflammatory Bowel Disease. World J Gastroenterol (2020) 26(32):4866-77. doi: 10.3748/ wjg.v26.i32.4866

222. Dong X-Y, Wu M-X, Zhang H-M, Lyu H, Qian J-M, Yang H. Association Between Matrix Gla Protein and Ulcerative Colitis According to DNA Microarray Data. Gastroenterol Rep (2019) 8(1):866-75. doi: 10.1093/ gastro/goz038

223. Li X, Wei R, Wang M, Ma L, Zhang Z, Chen L, et al. MGP Promotes Colon Cancer Proliferation by Activating the NF- $\kappa B$ Pathway Through Upregulation of the Calcium Signaling Pathway. Mol Ther Oncolytics (2020) 17:371-83.
Conflict of Interest: The authors declare that the research was conducted in the absence of any commercial or financial relationships that could be construed as a potential conflict of interest.

Publisher's Note: All claims expressed in this article are solely those of the authors and do not necessarily represent those of their affiliated organizations, or those of the publisher, the editors and the reviewers. Any product that may be evaluated in this article, or claim that may be made by its manufacturer, is not guaranteed or endorsed by the publisher.

Copyright $\odot 2022$ Lai, Masatoshi, Ma, Guo and Zhang. This is an open-access article distributed under the terms of the Creative Commons Attribution License (CC BY). The use, distribution or reproduction in other forums is permitted, provided the original author(s) and the copyright owner(s) are credited and that the original publication in this journal is cited, in accordance with accepted academic practice. No use, distribution or reproduction is permitted which does not comply with these terms. 


\section{GLOSSARY}

\begin{tabular}{|c|c|}
\hline AHR & anti-hydroxyl radical \\
\hline AMP & adenosine 5\&prime;-monophosphate \\
\hline AMPK & the AMP-activated protein kinase \\
\hline APDN & adiponectin \\
\hline ASA & anti-superoxide anion \\
\hline BMD & bone mineral density \\
\hline CAT & catalase \\
\hline CD & Crohn\&rsquo;s disease \\
\hline CD 36 & the cluster-determinant 36 \\
\hline CKD & chronic kidney disease \\
\hline CLCN4 & chloride channel-4 \\
\hline $\mathrm{CM}$ & chylomicron \\
\hline cOC/ucOC & $\begin{array}{l}\text { the carboxylated osteocalcin/undercarboxylated osteocalcin } \\
\text { ratio }\end{array}$ \\
\hline $\mathrm{CR}$ & chylomicron remnant \\
\hline CRC & colorectal cancer \\
\hline dp-ucMGP & dephosphorylated-uncarboxylated \\
\hline DSS & dextran sodium sulfate \\
\hline DVT & venous thrombosis \\
\hline GAS6 & growth arrest-specific protein 6 \\
\hline GGCX & $\gamma$-glutamyl carboxylase \\
\hline GIB & gastrointestinal bleeding \\
\hline Gla & $\gamma$-carboxyglutamate \\
\hline Glu & glutamate \\
\hline GSH & glutathione \\
\hline GSH-Px & glutathione peroxidase \\
\hline GR & glutathione reductase \\
\hline GST & glutathione-S-transferase \\
\hline HDAC & histone deacetylase \\
\hline hsCRP & high sensitivity C-reactive protein \\
\hline IAP & intestinal alkaline phosphatase \\
\hline IBDs & inflammatory bowel diseases \\
\hline $\mathrm{K}_{1}$ & vitamin $\mathrm{K}_{1}$ \\
\hline $\mathrm{K}_{2}$ & vitamin $\mathrm{K}_{2}$ \\
\hline LB & Lactobacillus \\
\hline LPS & lipopolysaccharide \\
\hline MDA & malondialdehyde \\
\hline MGP & matrix Gla protein \\
\hline MK & menaquinones \\
\hline MSCs & Mesenchymal stromal cells \\
\hline NPCIL1 & the Niemann-Pick C1-like 1 \\
\hline NOACs & non-VK antagonist oral anticoagulants \\
\hline PC & protein $\mathrm{C}$ \\
\hline PRGP & proline-rich Gla proteins \\
\hline $1,25(\mathrm{OH})$ & 25-dihydroxyvitamin D3 \\
\hline $2 \mathrm{D} 31 \alpha$ & \\
\hline ROS & reactive oxygen species \\
\hline SI & sucrase-isomaltase \\
\hline SIBO & small-intestinal bacterial overgrowth \\
\hline SCFAs & short-chain fatty acids \\
\hline SOD & superoxide dismutase \\
\hline SR-BI & the scavenger receptor class B-type I \\
\hline TG & triglyceride \\
\hline TMG & transmembrane Gla proteins \\
\hline TNF- $\alpha$ & tumor necrosis factor-alpha \\
\hline UBIAD1 & the UbiA prenyltransferase domain-containing protein 1 \\
\hline UC & ulcerative colitis \\
\hline VK & vitamin $\mathrm{K}$ \\
\hline VDR & the nuclear receptor vitamin D receptor \\
\hline VKDPs & VK-dependent proteins \\
\hline VKO & VK epoxide \\
\hline VKOR & VK epoxide reductase \\
\hline
\end{tabular}

